\title{
PSL Icing Facility Upgrade Overview
}

\author{
Thomas A. Griffin ${ }^{1}$ and Dennis J. Dicki ${ }^{2}$ \\ NASA Glenn Research Center, Cleveland, Ohio 44135 \\ and \\ Paul J. Lizanich ${ }^{3}$ \\ Sierra Lobo Corporation, Cleveland, Ohio 44135
}

\begin{abstract}
The NASA Glenn Research Center Propulsion Systems Lab (PSL) was recently upgraded to perform engine inlet ice crystal testing in an altitude environment. The system installed 10 spray bars in the inlet plenum for ice crystal generation using 222 spray nozzles. As an altitude test chamber, the PSL is capable of simulating icing events at altitude in a groundtest facility. The system was designed to operate at altitudes from 4,000 to 40,000 ft at Mach numbers up to $0.8 \mathrm{M}$ and inlet total temperatures from -60 to $+15{ }^{\circ} \mathrm{F}$. This paper and presentation will be part of a series of presentations on PSL Icing and will cover the development of the icing capability through design, developmental testing, installation, initial calibration, and validation engine testing. Information will be presented on the design criteria and process, spray bar developmental testing at Cox and Co., system capabilities, and initial calibration and engine validation test. The PSL icing system was designed to provide NASA and the icing community with a facility that could be used for research studies of engine icing by duplicating in-flight events in a controlled ground-test facility. With the system and the altitude chamber we can produce flight conditions and cloud environments to simulate those encountered in flight. The icing system can be controlled to set various cloud uniformities, droplet median volumetric diameter (MVD), and icing water content (IWC) through a wide variety of conditions. The PSL chamber can set altitudes, Mach numbers, and temperatures of interest to the icing community and also has the instrumentation capability of measuring engine performance during icing testing. PSL last year completed the calibration and initial engine validation of the facility utilizing a Honeywell ALF502-R5 engine and has duplicated in-flight roll back conditions experienced during flight testing. This paper will summarize the modifications and buildup of the facility to accomplish these tests.
\end{abstract}

$\begin{array}{ll} & \\ \text { A/D } & =\text { analog/digital } \\ \text { ARRA } & =\text { American Recovery and Reinvestment Act } \\ \text { ATP } & =\text { Aeronautics Test Program } \\ \text { CDP } & =\text { cloud droplet probe } \\ \text { CIP } & =\text { cloud imaging probe } \\ \text { DCS } & =\text { distributed control system } \\ \text { DI } & =\text { deionized } \\ \text { DPU } & =\text { data processing unit } \\ \text { DVD } & =\text { digital video disc } \\ \text { DVR } & =\text { digital video recorder } \\ \text { EHWG } & =\text { Engine Harmonization Working Group } \\ \text { FAA } & =\text { Federal Aviation Administration }\end{array}$

${ }^{1}$ PSL Mechanical Tech Lead, Wind Tunnel and Propulsion Test Branch, 21000 Brookpark Road, Cleveland, OH, 44135. ${ }^{2}$ PSL Lead Facility Engineer, Wind Tunnel and Propulsion Test Branch, 21000 Brookpark Road, Cleveland, OH, 44135. ${ }^{3}$ PSL Electrical Tech Lead, Sierra Lobo Corporation, 21000 Brookpark Road, Cleveland, OH, 44135. 


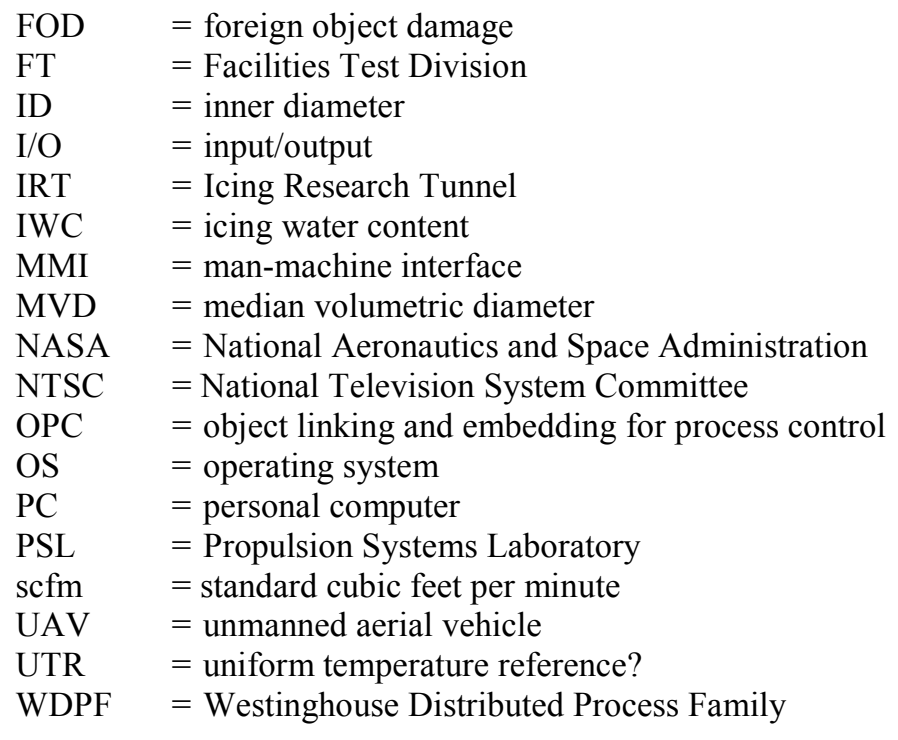

\section{Introduction}

$\mathrm{T}$ he Propulsion Systems Laboratory (PSL) at the NASA Glenn Research Center is one of the premier U.S. facilities for research on advanced aeropropulsion systems. The facility can simulate a wide range of altitude and Mach number conditions while supplying the aeropropulsion system with all the support service necessary to operate at those conditions. Test data are recorded on a combination of steady-state and high-speed data acquisition systems. For over three years, the PSL has undergone a significant transformation: an ice crystal cloud generation system was added, making it the first ground-based test facility in the world capable of fully simulating these challenging atmospheric conditions, which have been a longstanding threat to aircraft engines. Following the completion of the facility's first engine icing test, which resulted in the successful replication of a known altitude icing loss of power engine event condition, the facility staff are further augmenting the facility capability in response to ever-evolving research requirements to improve the efficiency of the testing process and to resolve known deficiencies in the system identified as part of the lessons-learned process.

\section{PSL Facility Background}

The Propulsion Systems Laboratory (PSL) at NASA Glenn Research Center in Cleveland, OH, houses two altitude simulation test chambers, which are used for aeronautics research of turbine engines. It consists of two chambers, PSL3 and PSL4, which are each $24 \mathrm{ft}$ in diameter and $39 \mathrm{ft}$ long. They are direct-connect facilities in which the engines are connected through inlet ducts to the inlet plenum. Each chamber utilizes the NASA GRC central air services for supply of pressurized air to set the inlet conditions and altitude exhaust for altitude simulation. Local to PSL are also J-57 heater engines and turbo-expanders, which provides nonvitiated temperature conditioning of the inlet air for Mach and altitude conditions (Fig. 1). Both test chambers were commissioned in 1973 for turbine engine research studies. They have been in continuous use since that time and have tested a wide variety of propulsion systems including military and commercial turbofan engines, turboshaft, turbine-based combine cycle, and unmanned aerial vehicle (UAV) engines. PSL is NASA's only ground-based, full-scale engine test capability designed for research to provide detailed information on the performance and operability of engines and propulsion systems at extreme conditions over the entire flight envelope, which can only be obtained through altitude-simulated ground-based testing. PSL overall facility capabilities are:

(1) Ambient air:

- $480 \mathrm{lbm} / \mathrm{s}$ at $55 \mathrm{psig}$

- $380 \mathrm{lbm} / \mathrm{s}$ at $150 \mathrm{psig}$

- $100 \mathrm{lbm} / \mathrm{s}$ at $450 \mathrm{psig}$

(2) Heated air:

- $39 \mathrm{lbm} / \mathrm{s}$ at $465 \mathrm{psia}, 1200 \times \mathrm{F}$

- $50 \mathrm{lbm} / \mathrm{s}$ at $50 \mathrm{psig}, 2670{ }^{\circ} \mathrm{F}$ (Mach 6.0)

(3) Cold air: 
- $330 \mathrm{lbm} / \mathrm{s}$ at $10 \mathrm{psig},-50^{\circ} \mathrm{F}$

- $30 \mathrm{lbm} / \mathrm{s}$ at $10 \mathrm{psig},-90^{\circ} \mathrm{F}$

(4) Altitude exhaust capabilities:

- Sea level at $750 \mathrm{lbm} / \mathrm{s}$

- $90,000 \mathrm{ft}$ at $18 \mathrm{lbm} / \mathrm{s}$

(5) Support services:

- $\mathrm{GH}_{2}, \mathrm{GO}_{2}$, natural gas, and liquid fuels

- Steam and hydraulics

- Six-component thrust system ( 50,000 lbf)

- 1600 channels data acquisition/display

- High-response transient data

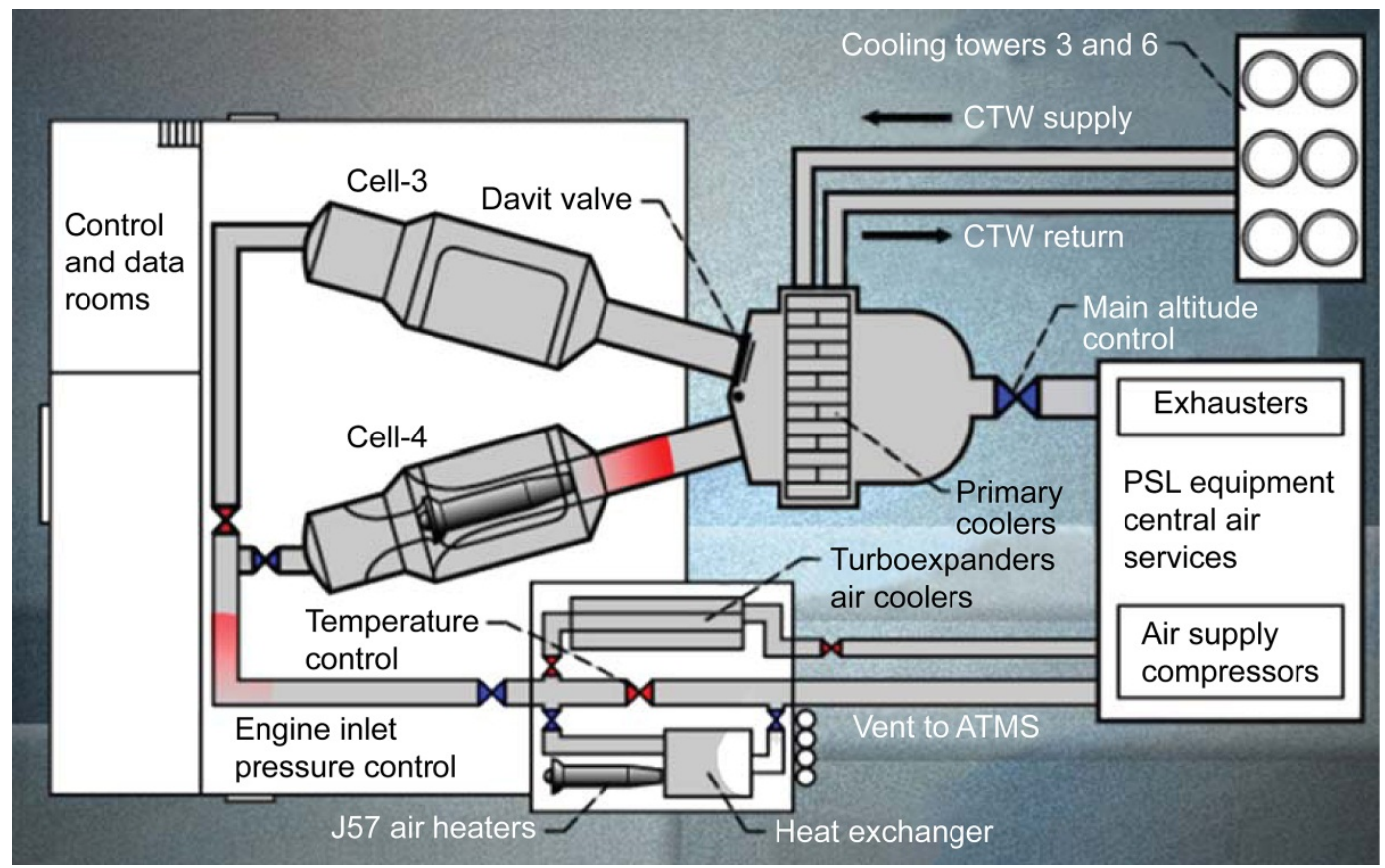

Figure 1. PSL functional layout.

PSL3 was recently upgraded in 2010 to 2012 for engine ice crystal research at altitude conditions. This paper will explain the enhancements made to the facility, the lessons learned, and the future enhancements planned.

\section{Advocacy for PSL Upgrade}

NASA Glenn has a strong icing research program dating back to the establishment of the Icing Research Tunnel (IRT) in World War II. ${ }^{1}$ Numerous icing flight campaigns have been conducted by the NASA GRC Icing Branch, including programs to characterize the natural icing environment, to collect data and study various aspects of the natural icing process, to study the aerodynamic effects of icing, and investigate methods to protect aircraft from icing. Many complimentary, similar, and even more extensive studies have been conducted by the Icing Branch in the IRT, where precise control over icing conditions greatly expand test utility. NASA has also developed the LEWICE icing code which predicts ice accretion and shapes on airfoil surfaces. ${ }^{2,3}$ The Icing Branch researchers and IRT operations engineers and technical staff represent world class experience in aircraft icing. Based on this and that PSL is uniquely suited to operate small- and medium-sized engines at varying altitudes and inlet conditions, the icing and altitude capabilities could be merged to position PSL to provide a capability to the icing community for a simulated flight environment to conduct both ice crystal and conventional icing research.

Based on the increased experience of engine power loss events since 1990, ${ }^{4}$ the technical staff at NASA began to advocate for the upgrade of the PSL to have a capability for ice crystal generation for engine research studies under simulated altitude conditions. Preliminary design studies were performed to consider different ice generation designs such as shaved ice and spray bars. Several companies and agencies such as Cox and Company, the Federal Aviation 
Administration (FAA), NASA GRC Icing Branch, and NASA Headquarters Aviation Safety Program provided input for design requirements. Input was also obtained from the FAA Engine Harmonization Working Group (EHWG), much of which was included in their 2005 roadmap, ${ }^{5}$ task 3 and 4, Mixed-Phase/Glaciated Icing Technology Plan. These tasks were titled:

(1) Task 3. Experimental testing in support of ice accretion model development and validation for high ice water content environments.

(2) Task 4. Test Facilities Requirements for demonstrating engine compliance with Appendix D requirements.

The EHWG endorsed the enhancement of the PSL for an ice crystal test capability in 2008 and a study was done of future utilization rates of the icing system in the PSL. It was determined that there was sufficient interest from the icing community to proceed with solicitation of funding sources for the facility icing system.

Ultimately the spray bar technique, similar to those used in the IRT, was selected as the most practical and gave the most versatility for use in the PSL. Utilizing the modulation of water supply pressure and atomizing air pressure would give a wide range of median volumetric diameter (MVD) distributions and icing water content (IWC). It was determined that the amount of material required to meet our requirements would make the shaved ice method impractical. The design envelope specified is presented in Table 1.

Table 1. PSL Icing Design Requirements

\begin{tabular}{|l|c|c|}
\hline \multicolumn{1}{|c|}{ Specification } & Minimum & Maximum \\
\hline Altitude (pressure), $\mathrm{ft}$ & 4000 & 40,000 \\
\hline Inlet total temperature, ${ }^{\circ} \mathrm{F}$ & -60 & 15 \\
\hline Mach number & 0.15 & 0.80 \\
\hline Air flow rate, $\mathrm{lbm} / \mathrm{s}$ & 10 & 330 \\
\hline IWC, $\mathrm{g} / \mathrm{m}^{3}$ & 0.5 & 9.0 \\
\hline MVD,$\mu \mathrm{m}$ & 40 & 60 \\
\hline Run time & \multicolumn{2}{|c|}{ Continuous up to 45 min } \\
\hline
\end{tabular}

Initial studies and preliminary designs were funded through the NASA Aeronautics Test Program (ATP). This provided accurate cost estimates for a detailed design and fabrication effort. Once funds became available from the American Recovery and Reinvestment Act (ARRA) of 2009, approval was given to proceed with final design, fabrication, and enhancement of the facility. The system was required to be removable so that the PSL3 can be reconfigured back to pre-icing configuration for standard engine research.

The modification was programmed in several different phases: the design phase, fabrication phase, icing system installation, icing calibration, and then an engine validation test. This was further separated into icing systems that included all of the systems necessary to generate the ice cloud in the plenum and test cell hardware, which would be hardware located in PSL3 utilized for the calibration and engine validation phases.

The facility modification, fabrication, and icing system installation was managed by the NASA Glenn Facilities Division. A.M. Kinney was selected as the prime contractor for the design with a subcontract to Cox and Company, Inc., for the spray bars and plenum transition duct. For part of the design effort, as a risk reduction, two demonstration tests of the spray bar design were performed at the Cox and Company LeClerc Icing Research Laboratory. A representative cross section of the spray bar was installed and velocities and residence times equivalent to the environment in the PSL were run to determine droplet freeze out and MVD distributions. Based on the results of these tests there was confidence to proceed forward with the spray bar and facility design under consideration.

Once the icing system was designed, fabricated, and installed the system was turned over to the Facilities Test Division (FT) for checkout and commissioning. This involved a lengthy process of verification of all of the wiring, control programming, instrumentation, and operation of the icing systems. This process took approximately 3 months to complete and was accomplished by initially performing end-to-end checks of instruments and valve and switch wiring, then individual component operation, and then complete subsystem operation and verification. A detailed checkout plan was written and performed before the systems were determined to be ready to operate collectively.

Separate from this design effort was the FT design and fabrication of the test cell hardware needed for the initial icing calibration and validation test. This included the remaining transition duct, which reduced the inlet diameter 
down to 36 in.; the instrumentation duct for location of the icing instrumentation; and the initial uniformity grid measurement system. The hardware was fabricated in house by the NASA GRC Fabrication Division.

The initial calibration of the icing system was performed in 2012. ${ }^{6}$ Although we drew on experience and techniques utilized in the IRT, there were differences in the operation of the facility, which required new procedures and techniques to be developed. The IRT is designed to create a cloud of supercooled liquid droplets. The PSL was initially designed to generate a cloud of frozen ice particles, although it has since demonstrated the capability of also performing conventional icing testing. There was the new cooling air system which sprays $-40^{\circ} \mathrm{F}$ service air at the nozzle discharge to aid with droplet freeze out. Operating procedures for the system had to be developed to optimize its effectiveness. Initial valve tuning had to be performed to optimized control response when sprays were initiated. The initial calibration was completed after 35 test periods. A cloud imaging probe (CIP) and cloud droplet probe (CDP) for cloud particle sizing; robust and multiwire probes for cloud water content; and a uniformity grid, tomography duct, and sheet laser for cloud uniformity are used to characterize the ice cloud. We calibrated the facility at flight altitude conditions and ice cloud conditions that would be used for the validation test.

The last phase of the ice system upgrade program was an engine validation test. NASA wished to conduct a series of validation tests of the new icing system, and a contractor, Honeywell, provided the test article for this validation test via a task order under the RTAPS contract. NASA would provide test time in PSL3 and Honeywell would provide an ALF502-R5 engine that previously experienced power loss due to ice crystal ingestion during a flight test. The design of the engine has since been changed to eliminate this issue. Thus we were able to use a unique engine that was instrumented for icing testing and had a characterized rollback condition. Under this contract the data were provided to Honeywell for use of the engine, and Government- use-only rights were provided to NASA for all of the data generated. The engine was installed in the PSL immediately after completion of the calibration test in 2012 (Fig. 2).

Using spray bar settings determined for the calibration to replicate the cloud conditions experienced during a flight test, flight 850 , the engine was successfully rolled back three times. The facility was then operated at conditions that the engine did not roll back during flight test, flight 855, and the engine did not roll back. An additional 86 test points where roll backs were identified and 37 no roll backs test points were performed. ${ }^{7}$

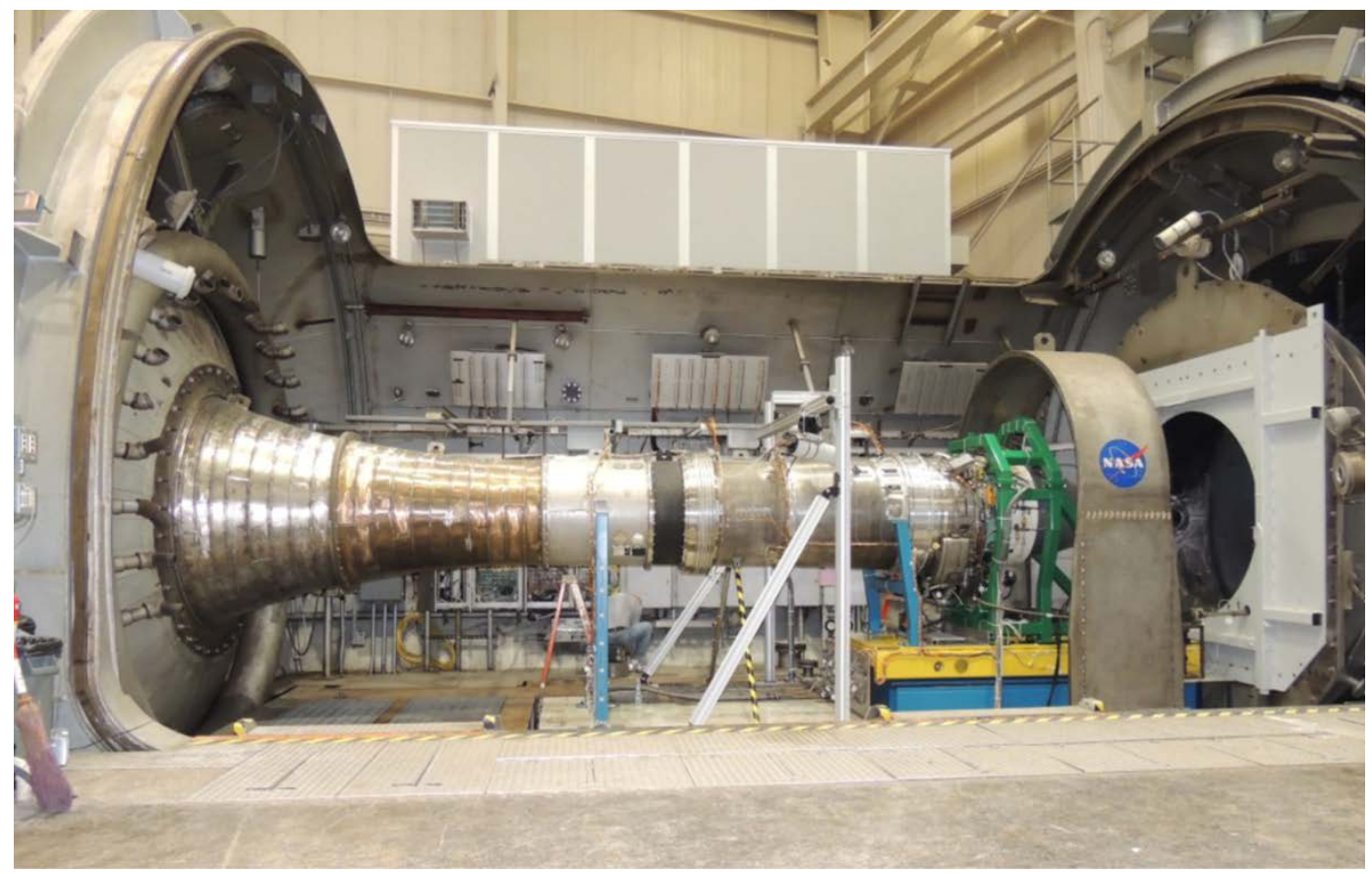

Figure 2. ALF502-R5 installation in PSL3. 


\section{Facility Modifications}

\section{A. Design of Facility Hardware for Calibration}

The design of the facility hardware that was required for the first calibration of the PSL Icing system was designed by one of NASA Glenn's in-house engineering contractors, Vantage Partners, LLC. They were given the task of providing design and fabrication drawings and specifications for all of the hardware including a transition duct, a tomography duct, a uniformity grid, a translating table, an instrumentation duct, a camera duct, and a powder spray system for coating the ice on the grid during cloud uniformity calibration. These items are shown in Figs. 3 and 4. This hardware enabled the icing researchers to gather data on the particle size, water content, and uniformity of the icing cloud that would be generated in PSL3 at various altitude conditions.

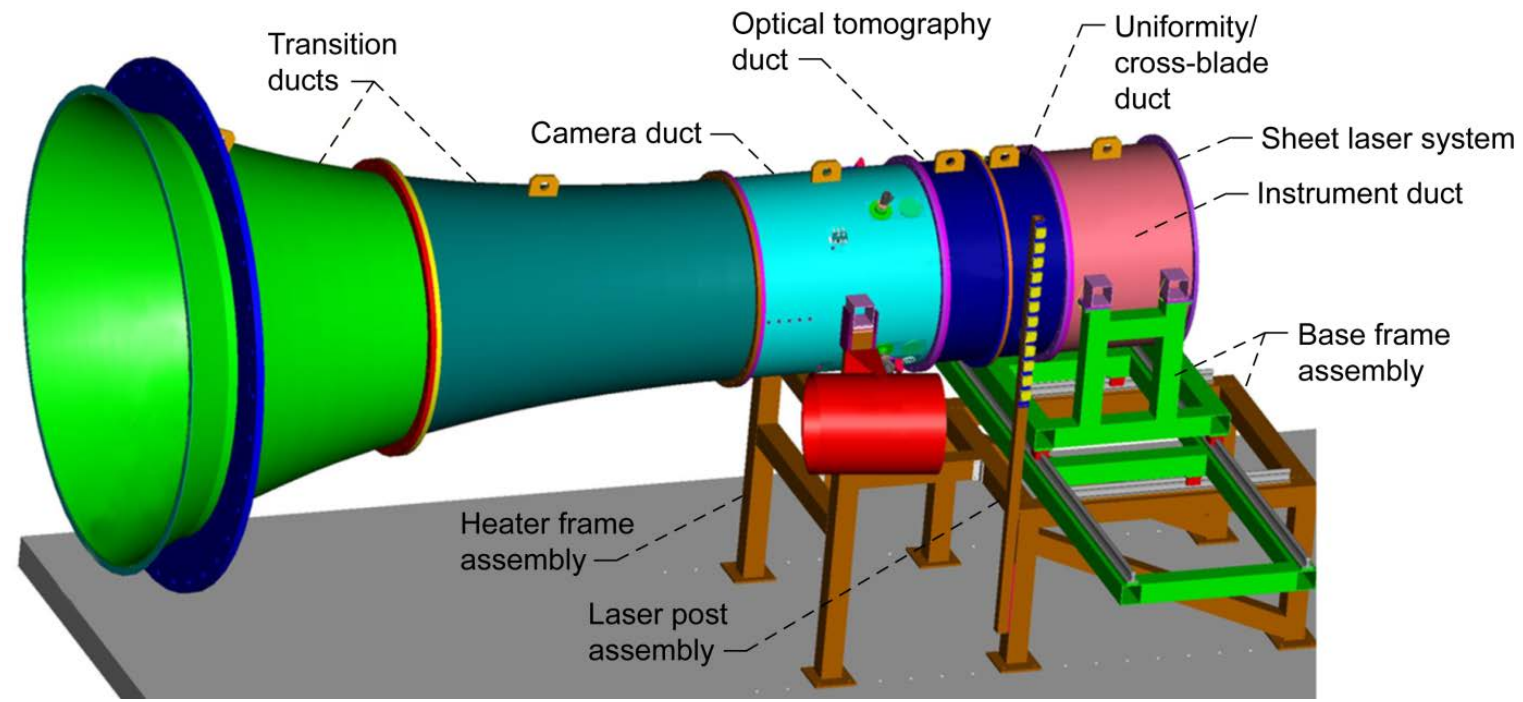

Figure 3. Icing calibration layout.

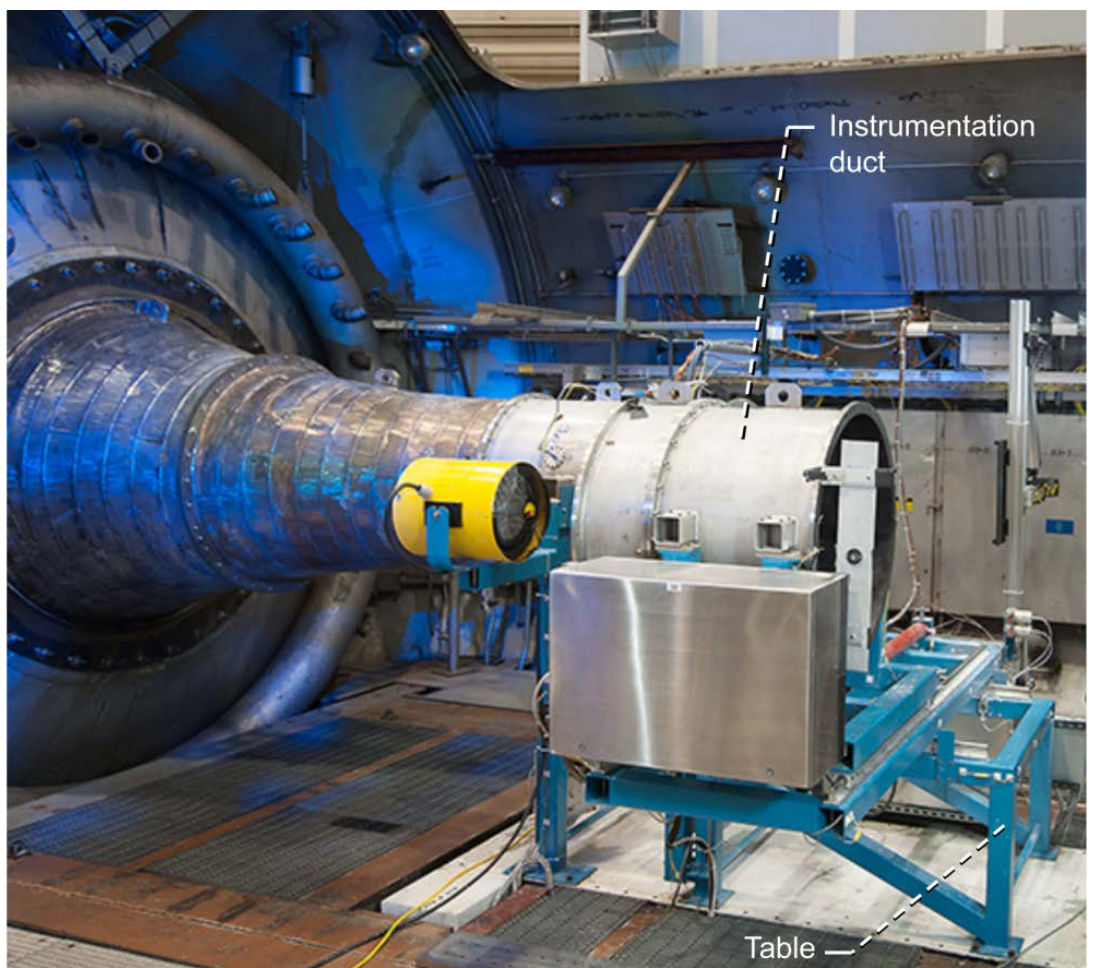

Figure 4. Icing calibration installation. 


\section{B. Icing Calibration Hardware}

Figures 3 and 4 show the calibration hardware installed into PSL3 prior to testing. The first two pieces on the left are transition ducts that reduce the diameter of the air stream from the 90-in. test cell bulkhead down to the 36-in. inner diameter (ID) ducting of all of the downstream ducts. The next piece to the right of the transition duct is the camera duct that houses the external cameras and the powder spray nozzles, followed by the tomography duct. The next duct is the instrument duct that is used to house all of the icing measuring instruments including the multiwire probe, robust probe, CDP, and CIP along with a cloud uniformity grid. The table at the far right was used in the uniformity portion of the calibration. The uniformity grid was inserted into the instrumentation duct and a supercooled liquid droplet spray was turned on until a predetermined amount of ice accreted on the grid. Then powder was sprayed onto the ice and the table slid the duct across a plane of lasers that measured the ice buildup, all remotely because the test section is sealed during tests. Finally the yellow heater was turned on to melt the ice. The table was then moved back into the air stream and ready for another test. Ice particle cloud uniformity was later verified using the sheet laser and tomography systems.

\section{Plenum Modifications}

(1) Removal of FOD screen: The inlet plenum that is upstream of the transition duct would normally contain an inlet bellmouth and a foreign object damage (FOD) screen that is the last form of protection for an engine during normal altitude engine testing. This must be removed for all icing tests. Its removal is shown in Figs. 5 and 6 . The inlet bellmouth and FOD screen are replaced with carbon fiber transition sections.

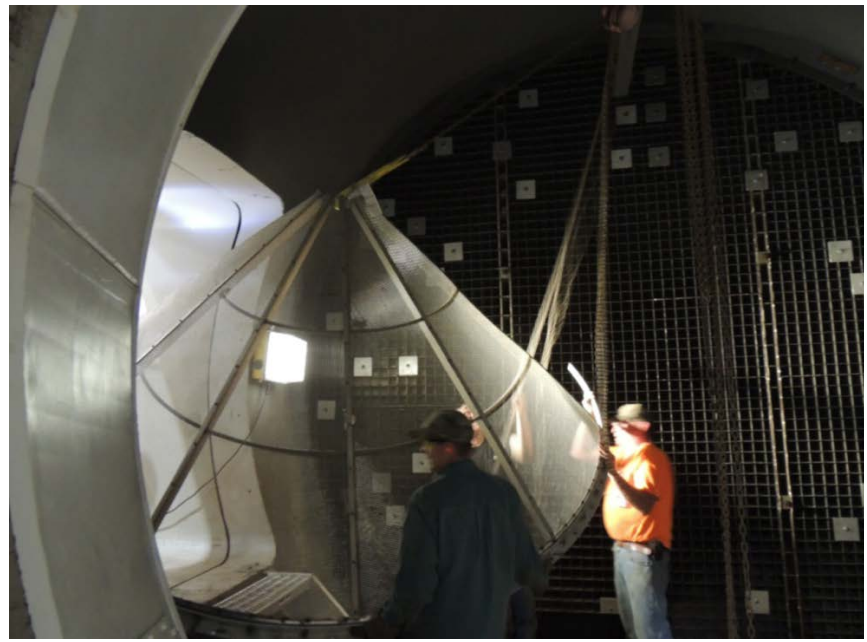

Figure 5. FOD screen removal.

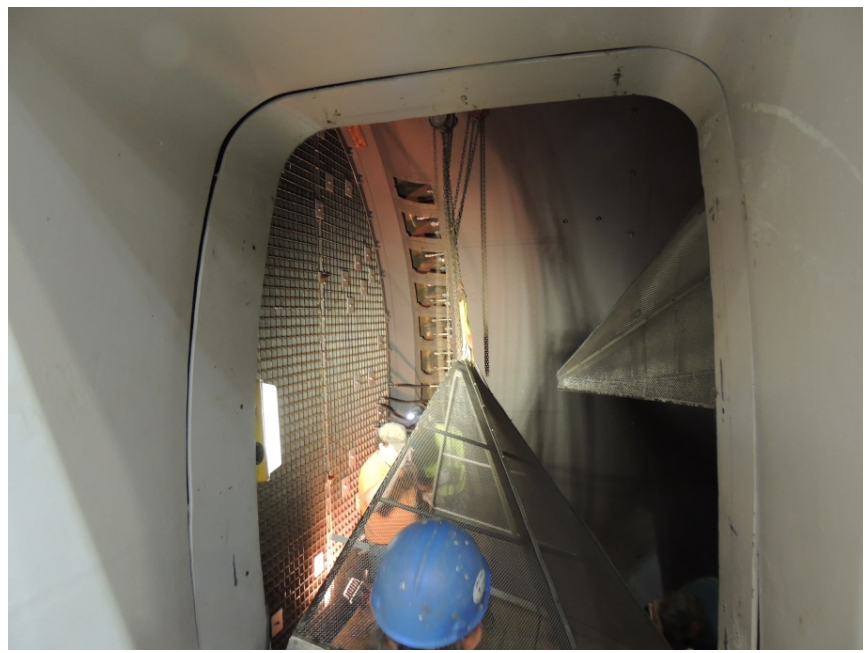

Figure 6. FOD screen disassembly. 
(2) Carbon fiber transition panel: After the FOD screen is removed, carbon fiber panels are installed into the plenum to reduce the plenum diameter From $\sim 16 \mathrm{ft}$. down to the 90 -in.-diameter test cell bulkhead. These panels are coated with a special conductive material that allows the surface to be grounded and reduces the chance of ice buildup that may occur because of a static charge from the ice particles (Fig. 7). Two of the lower sections also contain cameras for monitoring the spray bar nozzle performance during testing.

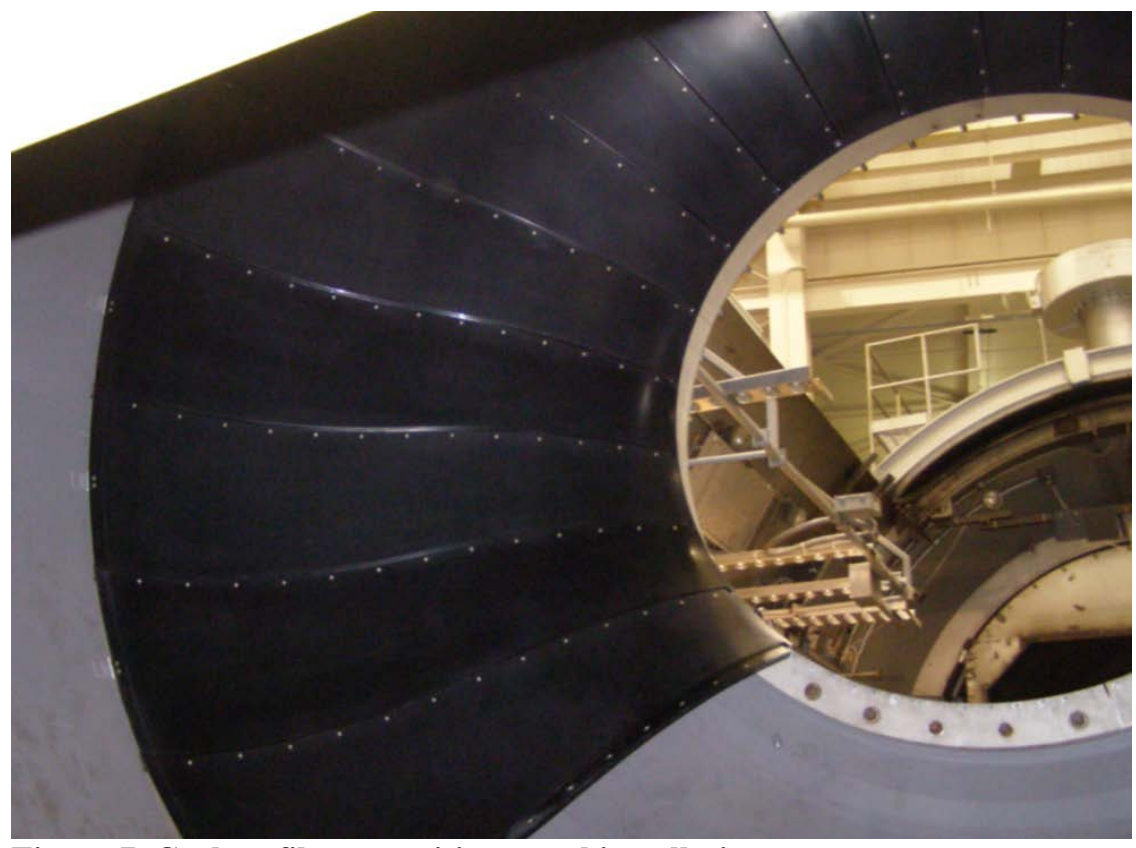

Figure 7. Carbon fiber transition panel installation.

(3) Spray bar support structure: The spray bar support structure is made from stainless steel structural tubing that will support each spray bars at three locations: the center and both sides as shown in Fig. 8. It is positioned just downstream of the existing plenum flow straightener. The spray bar supports are designed to be removable for reconfiguration of the plenum back to normal engine testing.

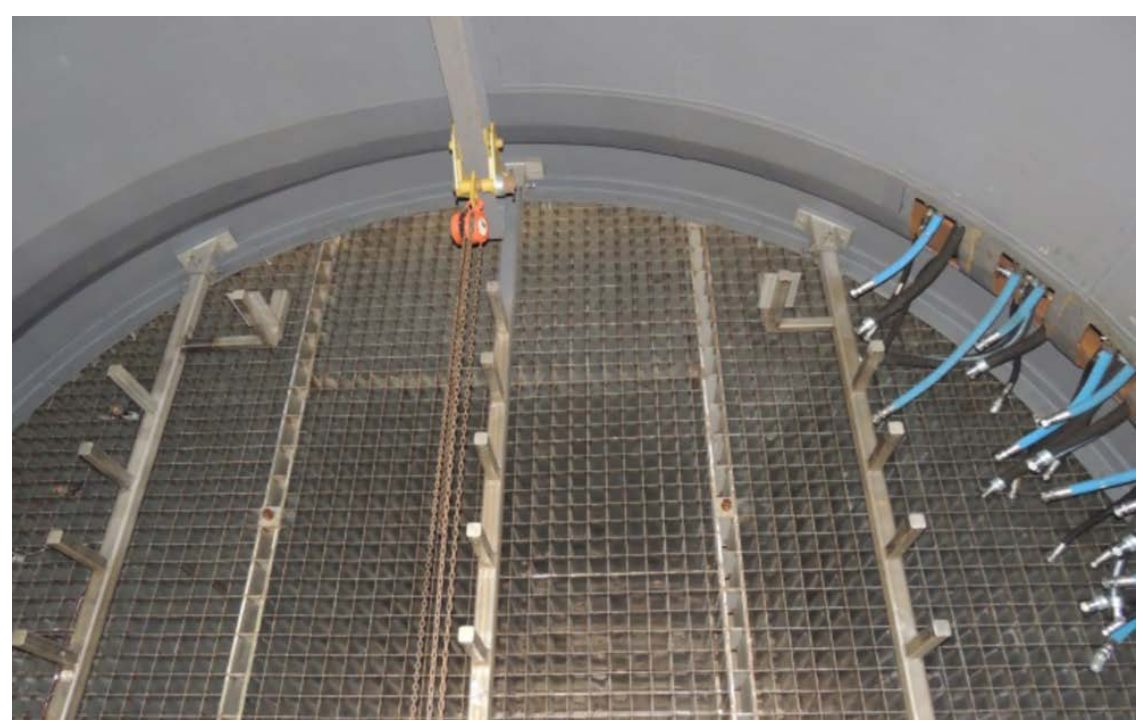

Figure 8. Spray bar support structure. 
(4) Plenum penetrations for spray bar supplies: All of the subsystems that feed the 10 equally spaced spray bars were fed into the plenum through several new penetrations (Fig. 9) that were made in the outer skin of the PSL3 plenum. From the penetration the atomizing air, cooling air and spray water pipes were routed around the ID of the plenum behind the plenum liner before exiting at the location of the proper spray bar. Hoses made the connection from the supply system piping to the actual spray bars (Fig. 10). These allowed for ease of installation and removal as well as provided thermal expansion relief.

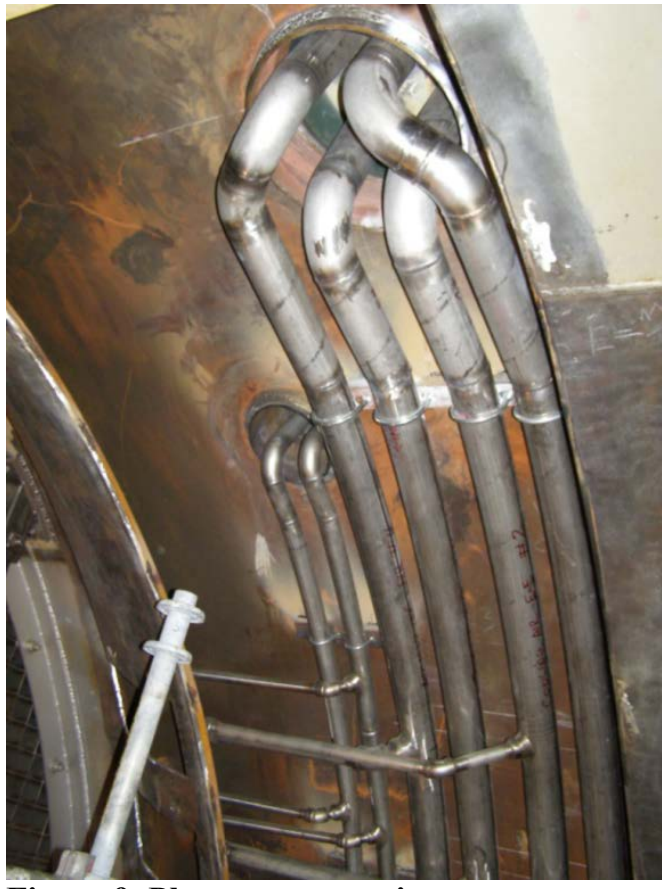

Figure 9. Plenum penetration.

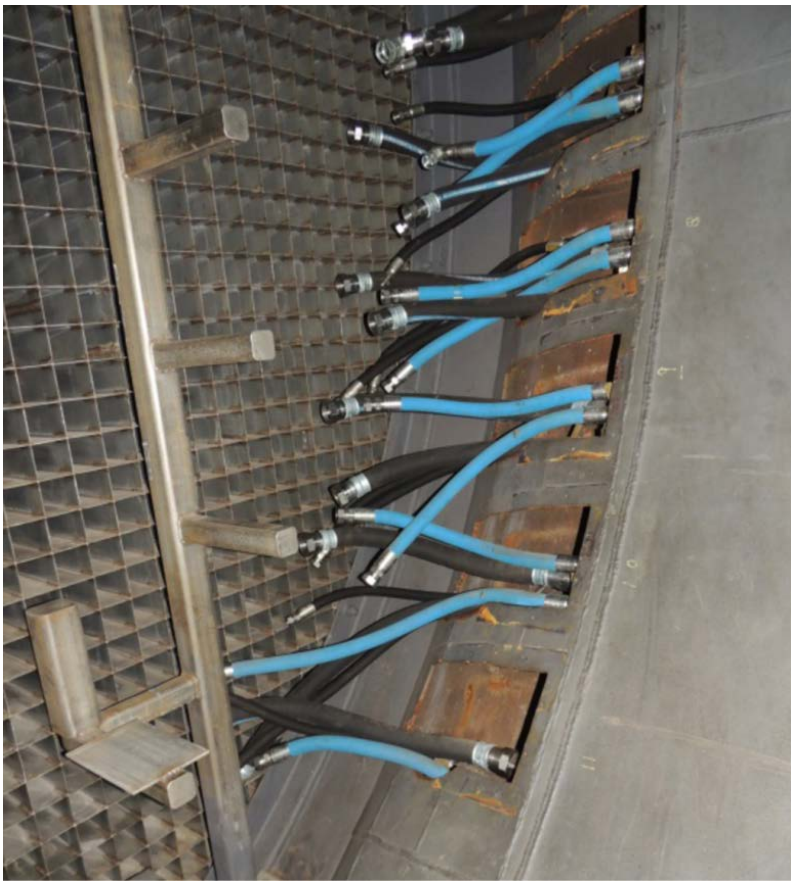

Figure 10. Supply hoses to spray bars.

\section{Spray Bar Configuration}

The 10 spray bars hold a total of 222 nozzles, 110 of the standard type and the 112 of the modified (Mod. 1) type that were both developed in GRC's IRT (see Fig. 11). The IRT nozzles have been developed over years of testing. The design, copied directly from the IRT with only minor modifications, has proven to produce a robust, repeatable water-atomizing nozzle. Standard nozzles have a larger hypodermic tube with higher water flow rate capability than the Mod. 1 nozzles.

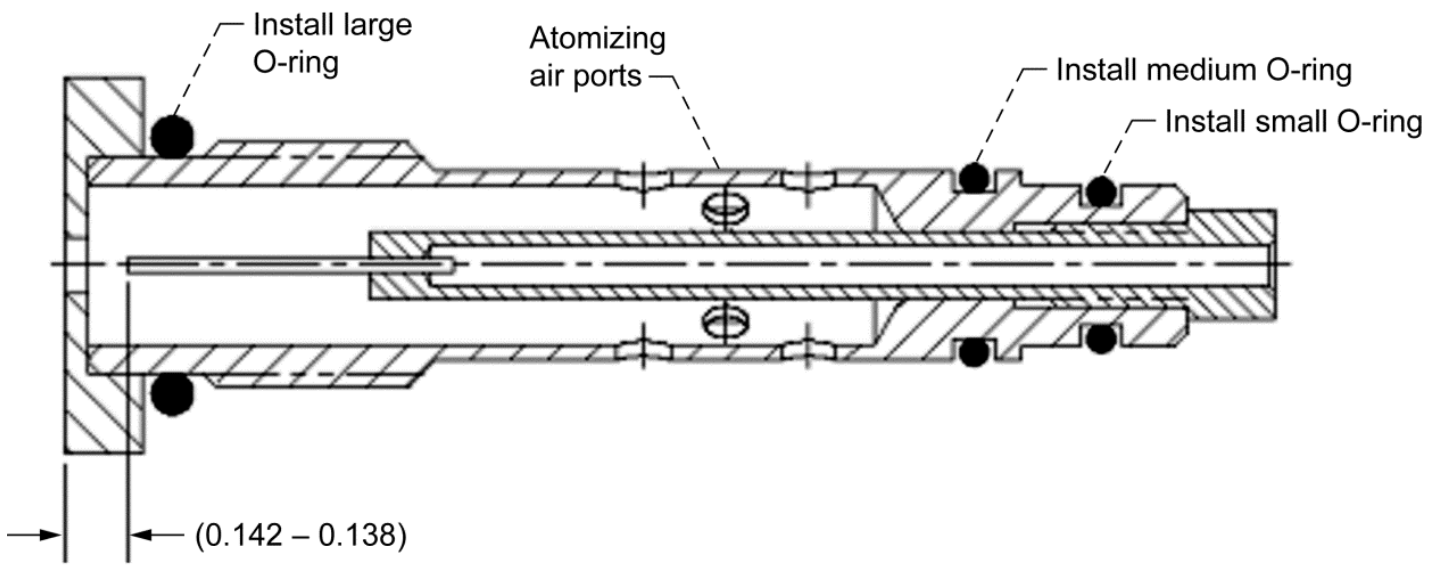

Figure 11. Icing spray nozzle cross section. 
High-pressure water is delivered through the center tube while lower pressure atomizing air enters the nozzle from the side, and the spray exits through the larger hole on the left.

The atomizing air is required to break up the larger water droplets that are formed when the high-pressure water exits the small tube in the center of the nozzle. This air pressure along with the correct water pressure determines the size of the particles that leave the body of the nozzle.

The cooling air distribution manifold is located on the aft end of the spray bar, and this manifold circles the spray nozzle (Fig. 12). The cooling air temperature can be as low as $-40^{\circ} \mathrm{F}$ and is used as needed to assist with droplet freeze-out by creating a local zone of cold air.

The 10 spray bars are primarily made out of fiberglass to allow them to be relatively lightweight (see Fig. 13). The spray bar pressure controls are in three zones to account for changes in head pressure for different mounting heights. There are three compartments in the spray bar; the leading compartment holds all of the wires for the nozzle solenoid valves, heater, and instrumentation. The center section is structurally the support for the bars, and it houses the atomizing air pipes, water pipes, individual spray water solenoid valves, and nozzle holders. The aft compartment houses the cooling air supply lines, cooling air nozzle, and spray nozzle. The middle and aft compartment are insulated and temperature monitored.

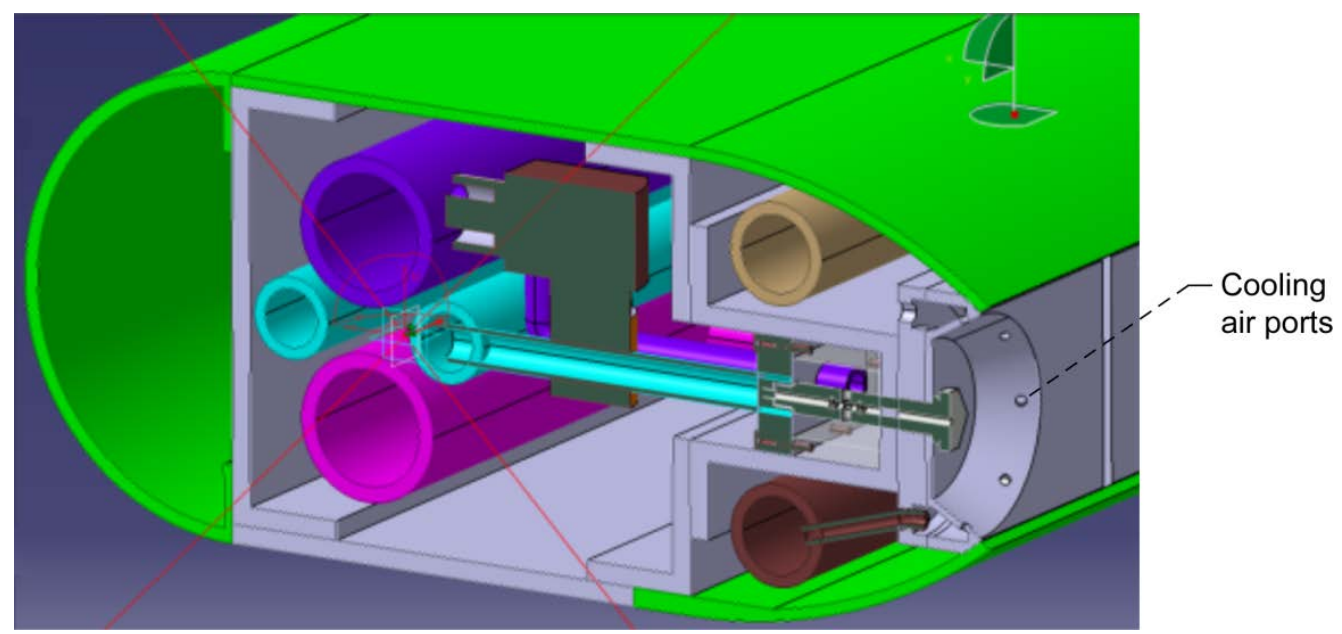

Figure 12. Spray bar cross section.

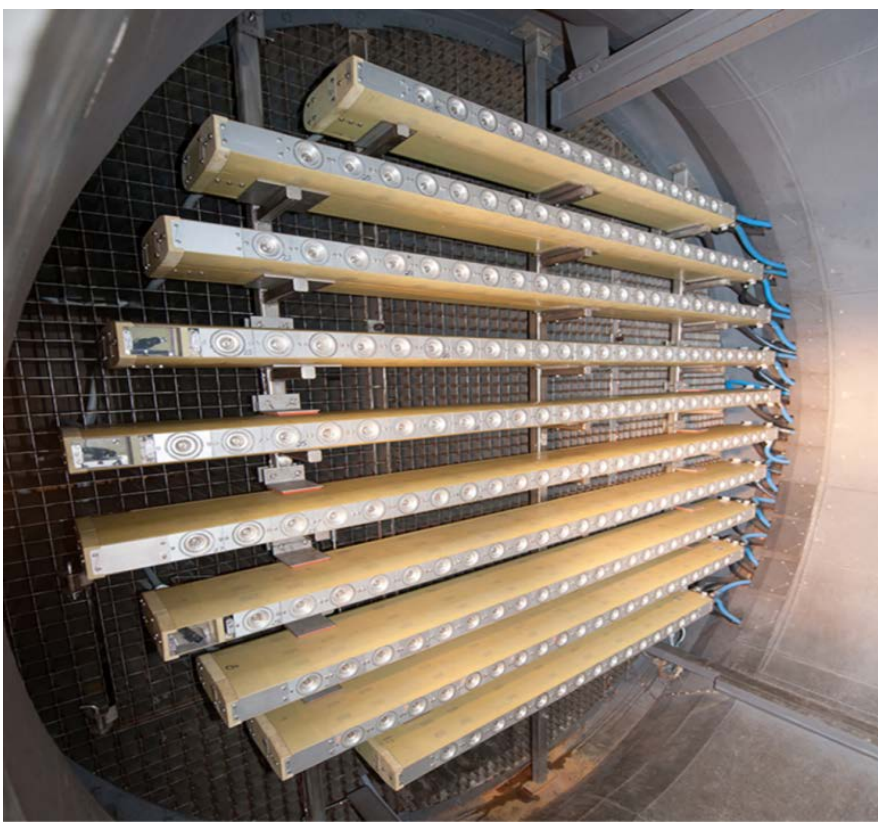

Figure 13. Spray bar installation in the inlet plenum. 


\section{Icing Spray System Modifications}

Overall, the icing spray system worked well during the first PSL engine icing test. The system as designed includes over 222 individually controlled spray nozzles that are alternated between two difference sets of nozzles, "Standard" and "Modified" (Mod. 1) lowflow nozzles. The main issue which required improvement was to reduce the occasional frozen nozzle. This phenomenon was observed primarily when a nozzle would be used early in the test run, then would not be required for a long period of time. The belief is the water which is dead-headed in the tube running through the solenoid and into the nozzle would freeze in place, precluding proper nozzle operation either by freezing in the solenoid or partially obstructing the flow path within the nozzle itself. Investigation after the testing showed the spray bar heating system as designed was insufficient. This design concentrated the heat trace along the water supply and return lines - ignoring the spray bar solenoid and nozzles all together. With the nominal operating point calling for water to be constantly recirculated through the spray bars back to the holding tank at a temperature well above freezing, it is believed there is little chance for the main water pipe to become frozen.

The existing heat trace was removed from the spray bars and has been replaced with a new three-zone heat trace system. One heat trace circuit is used to maintain heat on all solenoids in the spray bar. The heat trace circuit is used to wrap around each solenoid on the spray bar. A second heat trace circuit is used to wrap the standard nozzles, and a third to wrap the Mod. 1 nozzles. In addition, the insulation installed in the spray bars was greatly improved. Each of these heat trace zones are separately monitored through multiple type $\mathrm{T}$ thermocouples and should enable troublefree operation of the system.

\section{Steam System}

In a normal non-icing engine test the combustion air supplied to PSL is dried through desiccant dryer beds prior to being delivered to the facility. This enables the supplied combustion air line to operate as low as $-50{ }^{\circ} \mathrm{F}$ without freezing up the flow-straightening grid in the plenum ahead of the engine. However, in an icing environment this abnormally low dew point could create the situation where droplets lose volume/mass because of evaporation.

To mitigate this problem, the icing system design included a steam injection system. This steam injection occurs downstream of the turbo-expander air coolers at the combustion air control valves (Fig. 14). This is a high turbulence point in the combustion air system well upstream of the flow straighteners to enable thorough mixing. The desired operating point is a $50 \%$ relative humidity in the inlet plenum. This sets a dew point that remains just below the combustion air temperature to preclude ice forming on the flow straighteners while still maintaining a set relative humidity in the inlet plenum.

As an engine operates at higher altitudes, the total mass flow of air required is greatly reduced. The steam system as originally designed did not sufficiently account for this dramatic reduction of mass flow required, and it had difficulty maintaining a $50 \%$ relative humidity under some conditions. The steam system was modified to include a new low-flow leg, which permits stable control down to $0.025 \mathrm{lbm} / \mathrm{s}$ of steam.

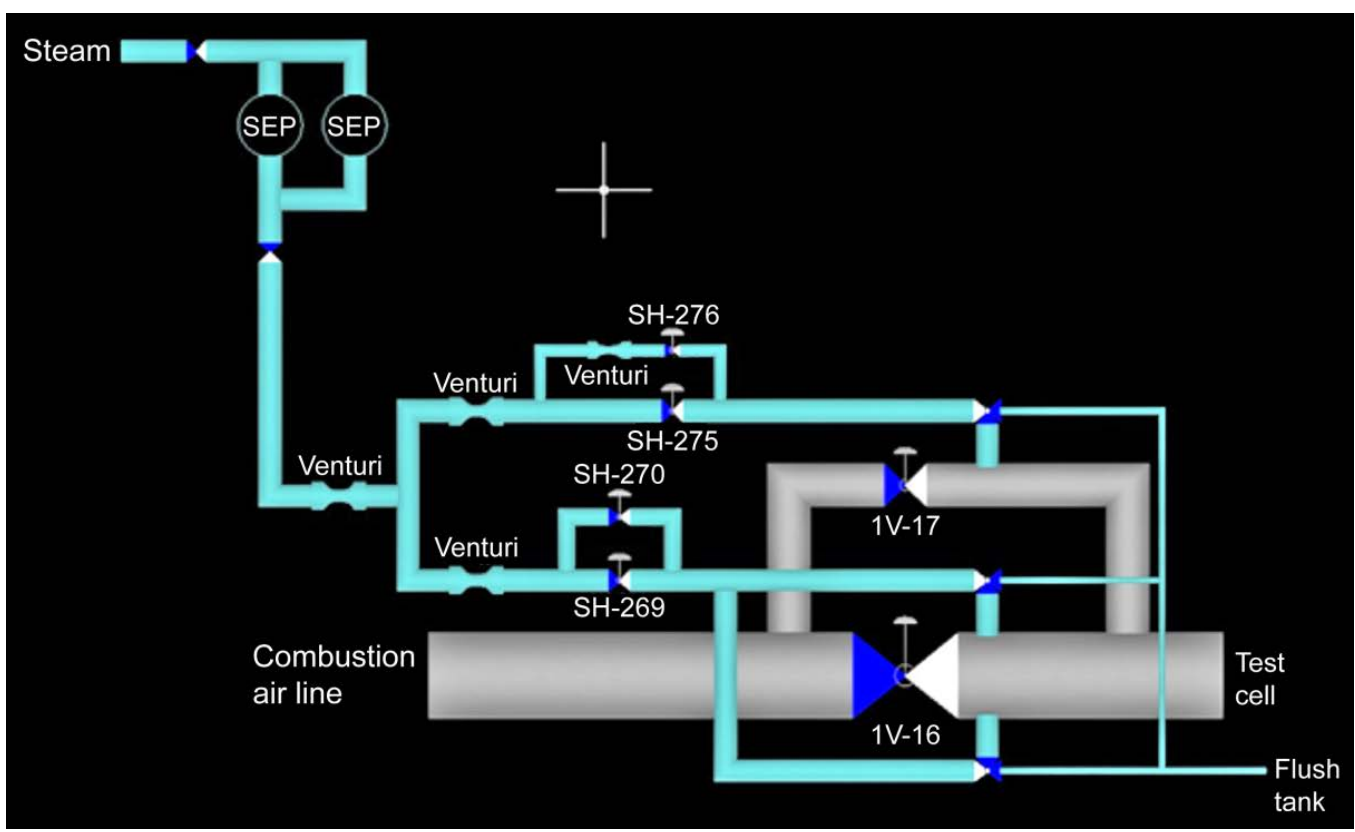

Figure 14. Steam injection system schematic for PSL. 
As described above, the PSL facility was designed for operation with cold dry air at altitude conditions. To measure the dew point of the provided air the facility relies upon a General Eastern dew point analyzer, which operates on a chilled mirror technology. This technology device is excellent for a steady-state measurement such as monitoring the moisture content of the combustion air after being processed by a dryer bed whose performance slowly degrades over the course of a test run. The steam injection system changed this philosophy to one that requires a measurement system having a much faster response. Step changes in dew point caused by the enabling or disabling of steam injection overwhelms the chilled mirror system, forcing the system into a 20-min-long PACER mirror cleaning cycle.

The facility has upgraded its dew point system to include three Spectra WVSS-II atmospheric water vapor sensors (Fig. 15), measuring the humidity at the point prior to steam injection, prior to the spray bars and just upstream of the engine face. The sensors are commonly used on commercial aircraft and provide an output with an update rate as short as $2.3 \mathrm{~s}$. Unlike a chilled-mirror technology system, these devices use a tunable diode laser absorption spectroscopy method, which is not overwhelmed by rapid changes to the humidity of the sample.

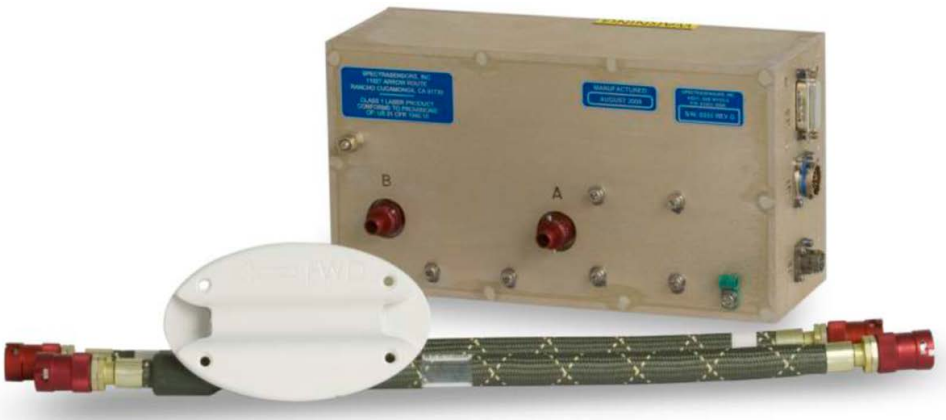

Figure 15. SpectraSensors water vapor sensor.

\section{Icing Support Systems}

Figure 16 displays the PSL icing support systems.

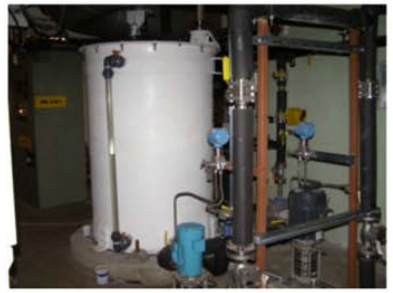

Water tank

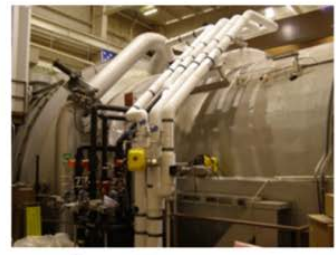

Outside test cell water supply and return pipe atomizing and cooling air supply

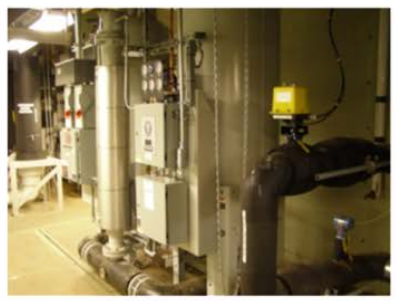

Air dryer

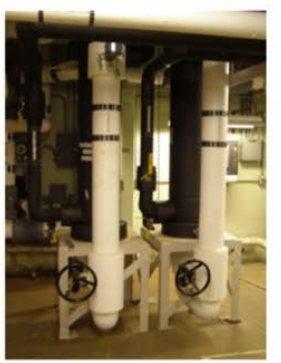

Cooling/atomizing air $\mathrm{HX}$

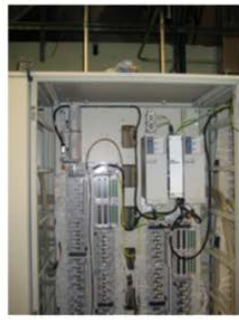

Controls
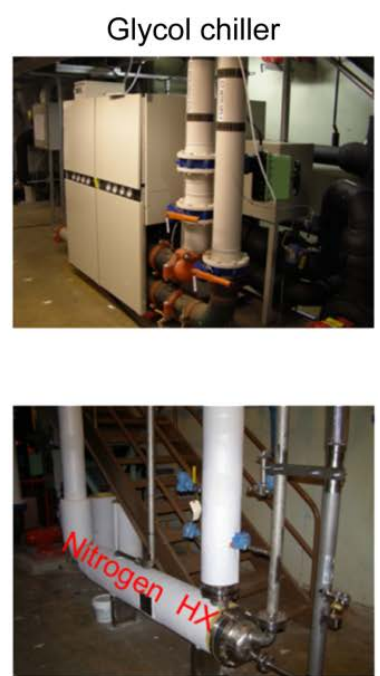

Figure 16. PSL icing system photographs. 

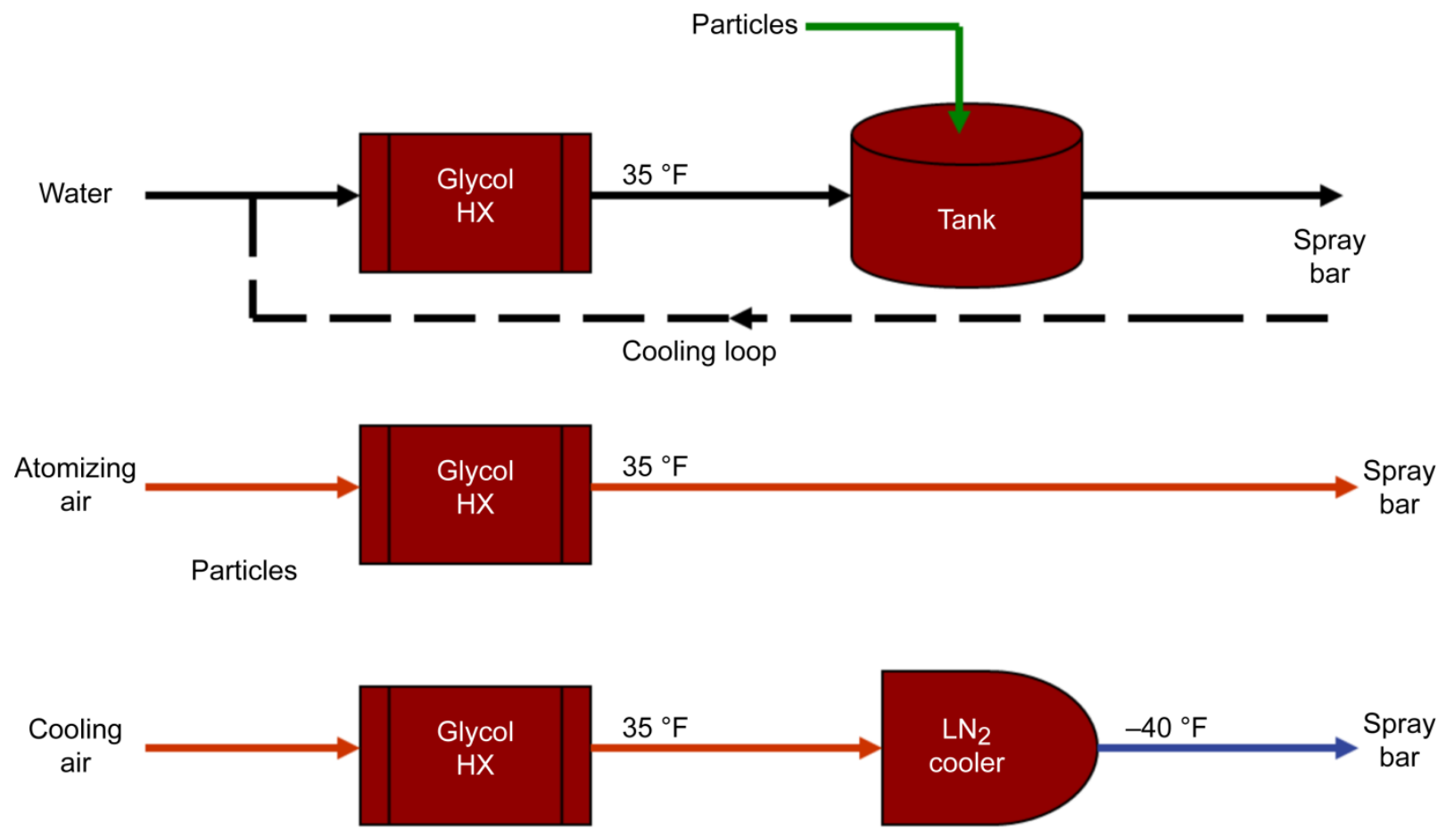

Figure 17. Icing subsystem diagram.

The first of the three main icing subsystems required for ice generation is the spray water system (Fig. 17). It was originally designed to supply high-pressure, cold city water to the spray bars. The spray water system has a mechanical chiller that can reduce the water temperature down to about $35^{\circ} \mathrm{F}$ before it is sent to a holding tank where batches of water-particle mix can be formulated. The water is then pressurized to 400 psig with a pair of water pumps and sent to the water control manifold, which splits the water into three separately controlled pressure zones that feed the spray bars. The three zones are used to minimize differences in pressure at the spray nozzles caused by differential water heads at the bars because of their different elevations. The water will flow through the spray bar and then return to the main holding tank with another set of control valves that close down when a spray begins so that the supply pumps maintain a constant flow and pressure with sprays on and off. The particle injection portion of this system was never used because it was found that city water has an adequate concentration of particles that become the nucleation sites of the ice particles. After the first engine test the researchers had requested that a deionized (DI) water system be installed because the city water used during the first engine test caused a considerable amount of buildup on the test engine's internal parts during the test. A 100-gpm DI water system has been installed in PSL and will be used during the next calibration test. It has the capability of delivering pure DI water or a blend of city water and DI as required to provide adequate particles for ice nucleation sites.

The atomizing air system (Fig. 17) brings in up to $2500 \mathrm{scfm}$ of shop air at $120 \mathrm{psig}$, filters it, and cools it down to around $35^{\circ} \mathrm{F}$. The air goes through a control station where a control valve reduces the pressure to meet the research test point condition requirements. There is a separate control valve for the standard nozzles and one for the Mod. 1 nozzles, and when air is delivered to the nozzle, it goes to every standard or Mod. 1 nozzle depending on which type of nozzle is selected.

The cooling air system (Fig. 17) also uses the facility shop air for its source. The air is dried with a desiccant dryer to a dew point temperature of $-40{ }^{\circ} \mathrm{F}$, and from there it enters a heat exchanger that brings the temperature down to $35^{\circ} \mathrm{F}$. It then goes to a liquid nitrogen heat exchanger, which brings it down to a temperature of $-40{ }^{\circ} \mathrm{F}$ before it goes to the control station behind the plenum where the pressure and flow rate are set to meet the research requirements. The system has a maximum flow rate of $2500 \mathrm{scfm}$.

\section{Design and Fabrication of Facility Hardware for Validation Test}

The calibration transition duct and tomography duct were used for the engine validation test. Downstream of these ducts a new labyrinth seal was designed, fabricated, and installed. The labyrinth seal is used during tests that utilize a thrust stand for measurement of engine thrust and isolates the facility from the engine inlet ducting. After 
this hardware, a new transition duct was made to increase the internal diameter from 36 to 40 in., which matches the inlet fan flange. The other major piece of hardware that was used was the $10 \mathrm{~K}$ thrust measurement stand.

Before icing tests were performed in the PSL, the primary types of video data obtained in the PSL were from four cameras in the test cell for monitoring the engine and a number of cameras outside the cell positioned around the facility monitoring for fuel or other leaks, and very importantly observing the aft of the engine for signs of sparks. Up to five of these cameras were overlayed with time code and recorded on medical-grade digital video disc (DVD) recorders. Engine icing has brought about a new level of importance to the observation of the engine under test.

For the first engine icing test a single standard National Television System Committee (NTSC) camera was used to observe the face of the engine. The camera was in an enclosure in the test cell peering through a window in the final section of inlet ducting (Fig. 18). Additional windows were present to provide lighting for this camera. The camera was canted at an angle to permit the viewing of the inlet guide vanes and/or splitter lip between the core and bypass of the engine. In addition, the facility added a number of cameras to observe the operation of the spray bars as well as monitoring the 27:1 contraction ratio for ice accretion. The continuous observation of this video during icing tests demonstrated their importance.

The facility has committed to improving the video capability. A new 16-channel digital video recorder (DVR) system is being installed to replace the five DVD recorders, and a new 20-channel time code overlay system is replacing the obsolete five-channel system. This will enable the recording by all five plenum cameras, as well as the typical four-cell cameras and other special cameras that are installed for a test.

In addition, an eight channel 1080-pixel camera system is being installed. For the next engine icing test a new camera duct is being fabricated with 16 ports to enable four engine quadrant views as well as a view of the entire engine face from a camera mounted dead-center on one of the spray bar supports in the inlet plenum. Additional control room monitors are being installed as required to display these new views.

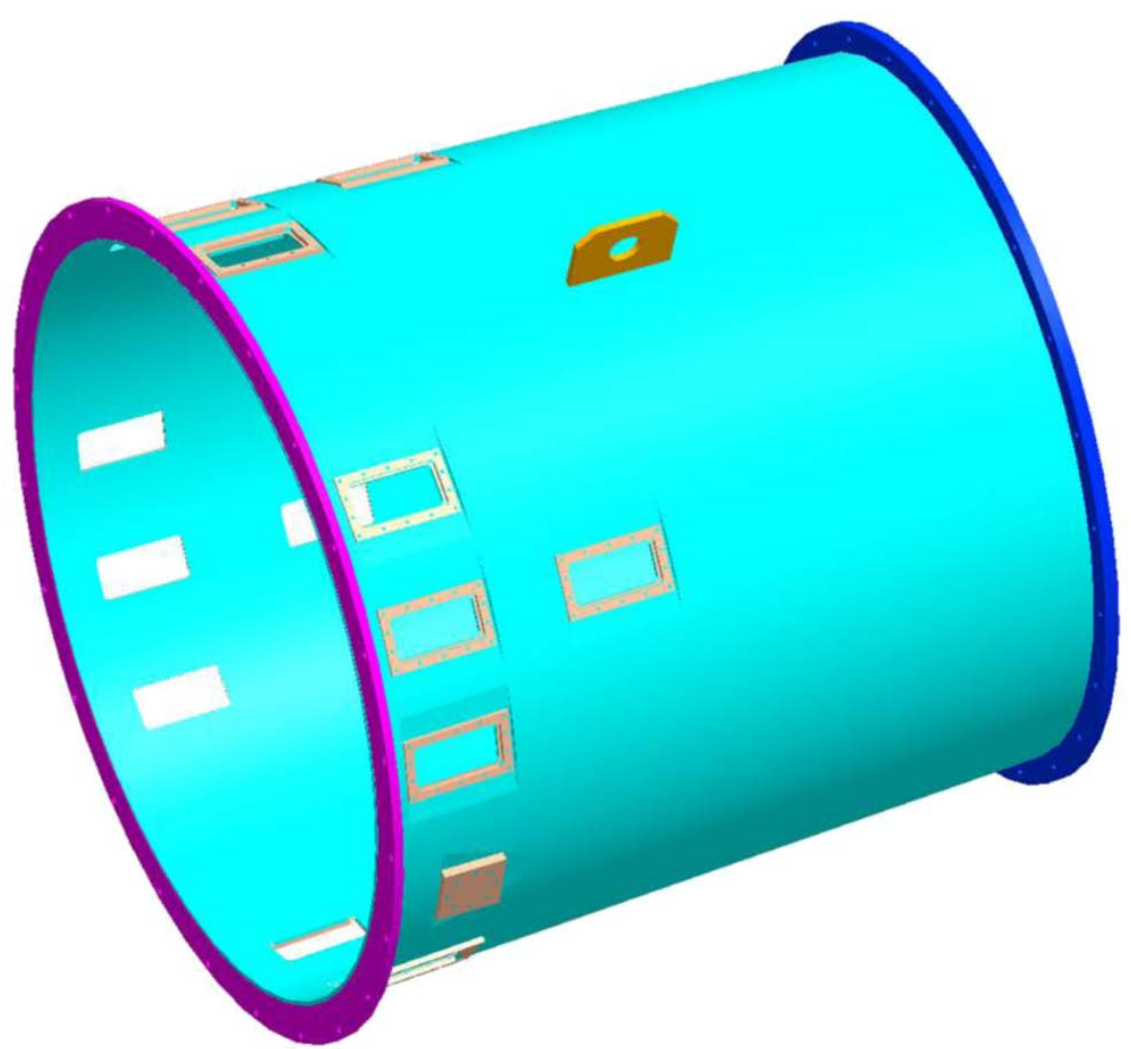

Figure 18. Instrument and camera duct. 


\section{Prototype Tomography System}

During the initial icing calibration a tomography duct was installed at the exit plane for cloud uniformity measurement. ${ }^{8}$ The system is nonintrusive and can be used for real time monitoring of spray bar performance and cloud uniformity (Fig. 19).

This advanced instrumentation was used for an in-situ measurement utilizing equally spaced laser diodes and receivers around the circumference of the duct. The system was utilized in conjunction with the sheet laser and uniformity grid with good correlation. The system demonstrated the ability to diagnose abnormal performance of the spray bars such as leaking nozzles, which were deliberately turned on at low flow rates (see Fig. 20). Another abnormal operation is two nozzles becoming inoperative during testing. This was also simulated and diagnosed using the tomography system as shown in Fig. 21.
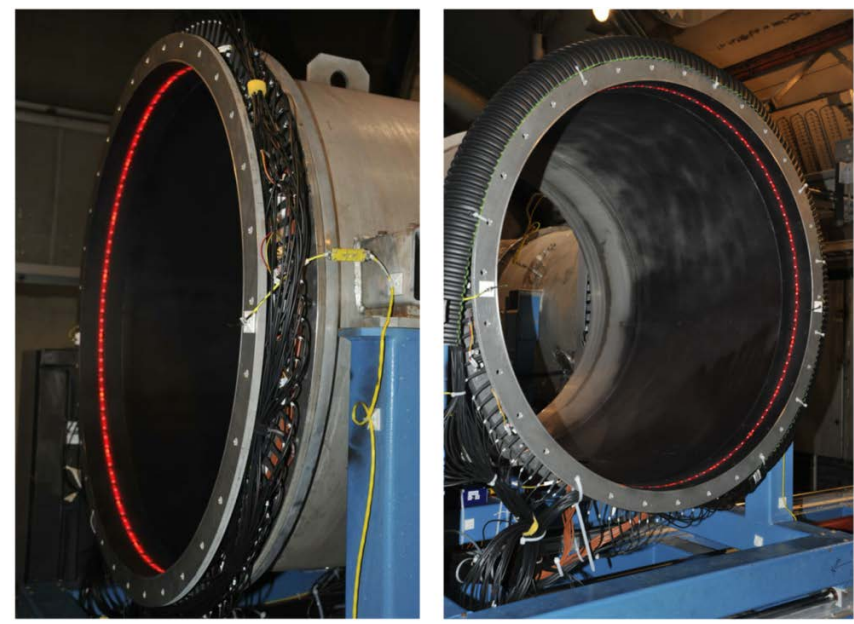

Figure 19. Tomography duct installation.
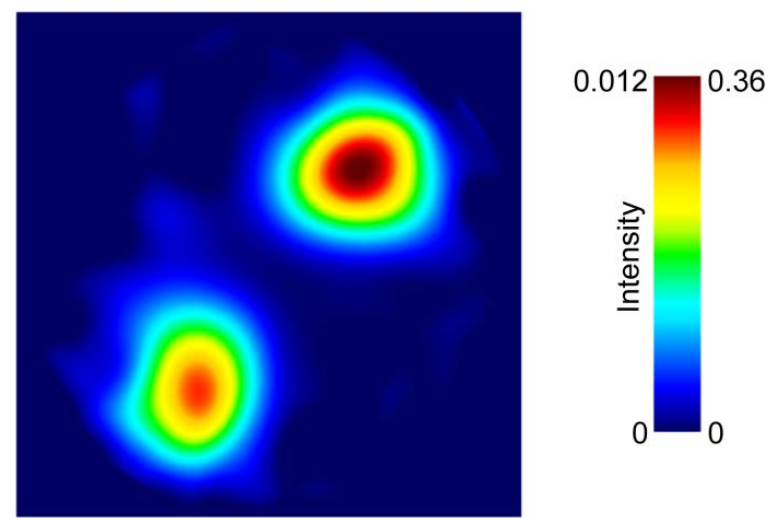

Figure 20. Leaking nozzle simulation image.

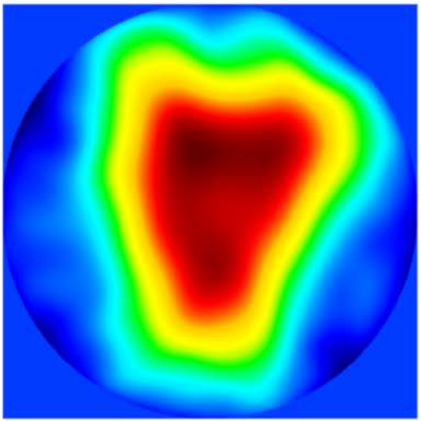

(a) 30 Nozzles.

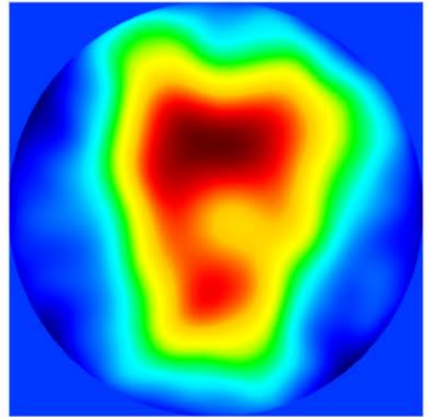

(b) 28 Nozzles.

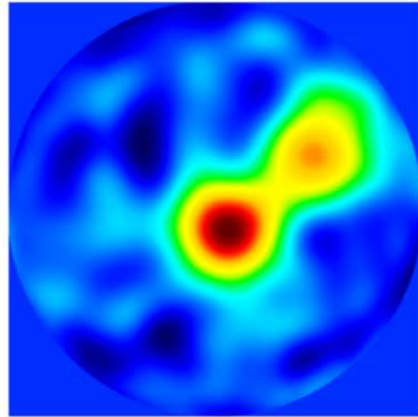

(c) Difference.

Figure 21. Inoperative nozzle simulation image. 


\section{Data System and Facility Control Modifications}

\section{COBRA Data System}

For decades the steady-state data system at GRC has been ESCORT. ESCORT is a system based around Neff 400/470/600 A/D (analog/digital) systems which are now 30+ years old. Neff itself is out of business. The system runs on HP/DEC Alpha computers running VMS, which are at least 15 years old and whose maintenance and repair services are now no longer available. The system architecture is central bus, which does not take advantage of modern computing systems or operating system (OS) designs. There is no ability for multicore, multithreading, or distributed processing.

The ESCORT system limits are similarly being pushed to the limit with every successive test in the PSL. There is a maximum of only 2000 input channels, 8000 calculations, and only 16 display screens. The system configuration is through ASCII configuration files, and the system operates on a command line interface.

The PSL is expecting to receive one of the first new COBRA data systems that will replace ESCORT. This system (Fig. 22) is designed around standard commercial hardware including personal computers (PCs), switches, data storage, and multiple vendors of $\mathrm{A} / \mathrm{D}$ converters. It will utilize commercial and open-source software running on multiple OS including Windows and Linux and will be capable of processing data with multiple programming languages. It is designed to be scalable in the number of displays, calculators, subsystems, and analog channels. The system will be completely configurable through an online interface. COBRA will effectively be both a steady-state and medium-speed data system offering multiple data acquisition rates of 12.5, 25, 50, 100, 200, 400, and 800 samples per second with digital signal processing and anti-aliasing. The maximum of display stations will be doubled to 32 .

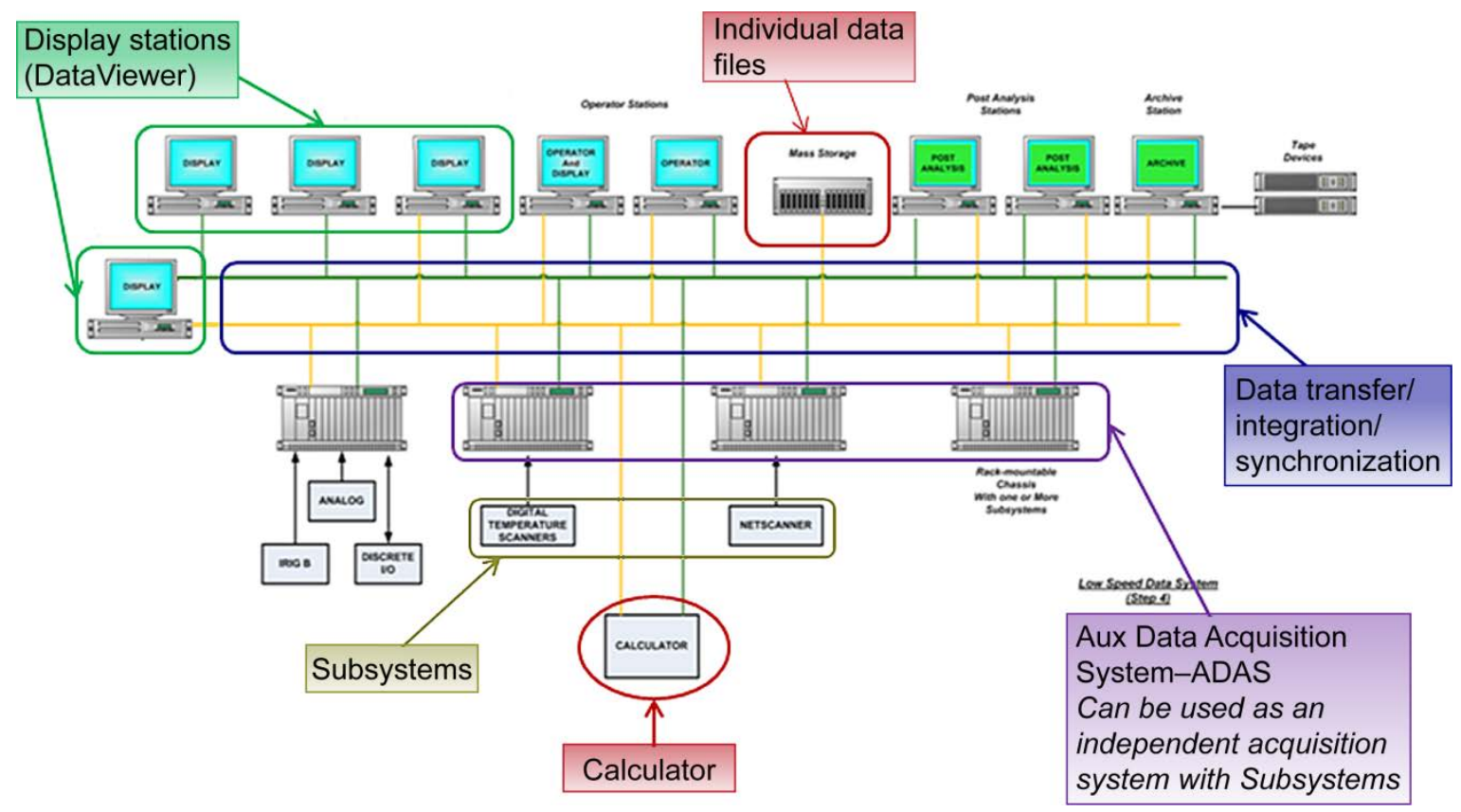

Figure 22. COBRA data system.

\section{Ovation System}

In the early 1990s a Westinghouse Distributed Process Family (WDPF) control system was installed in the PSL. The facility subsystems utilized almost 300 control sheets, which were spread across seven data processing units (DPUs). In the early 2000s, WDPF evolved into the Emerson Ovation product line. The PSL facility control system was upgraded to Ovation 2.2, running OCR-161 processors operating on AutoCAD-developed control sheets with Windows 2000 engineering stations and operator stations utilizing Windows NT servers, while retaining the WDPF Q-line I/O (input/output) cards. 
The icing system would require a significant expansion of the control system. The decision was made to break away from the use of 20-year-old Q-line I/O cards and augment the system with multiple remote drops near the new subsystems using the current line of Ovation I/O cards (see Fig. 23). The use of the current Ovation I/O cards required an upgrade of the control system to at least v3.0. Emerson has a process called Evergreen for the migration of older WDPF or Ovation systems to the up-to-date versions of Ovation. In 2010, the PSL performed a partial upgrade to Ovation v3.3.1. This upgrade included modern OCR400 controllers, migrating the control sheets from WDPF-era AutoCAD-based to Ovation E-CAD, and man-machine interface (MMI)/PC upgrades to Windows XP and Windows Server 2003 and 2008. With the changeover of control sheets a complete facility integrated system test of all subsystems was performed. This nearly 500-page-long, 8-week task culminated in a cold pipe test to fully certify that the facility was completely functional after the control system change.

Two remote drops were added to the PSL Distributed control system (DCS), one for analog signals and one for discrete signals. With the vast improvements in processor capability over the 20 years since the system was originally designed, these remote drops were added to a single processor, DPU 7. As part of a simultaneous DCS expansion, controls for two facility heater engines were moved to a remote drop off DPU 8, relieving DPU 7 of any tasks associated with operating one of those engines. The icing system alone requires 300 control sheets, which exceeds the total number of control sheets required to operate the facility prior to the installation of the icing or heater engine controls. The end-to-end checks of all signals, subsystem checkouts, and integrated system testing of the icing system culminating in a series of validation test runs was completed in 2012.

An image of the PSL Ovation DCS topology is presented in Fig. 23.

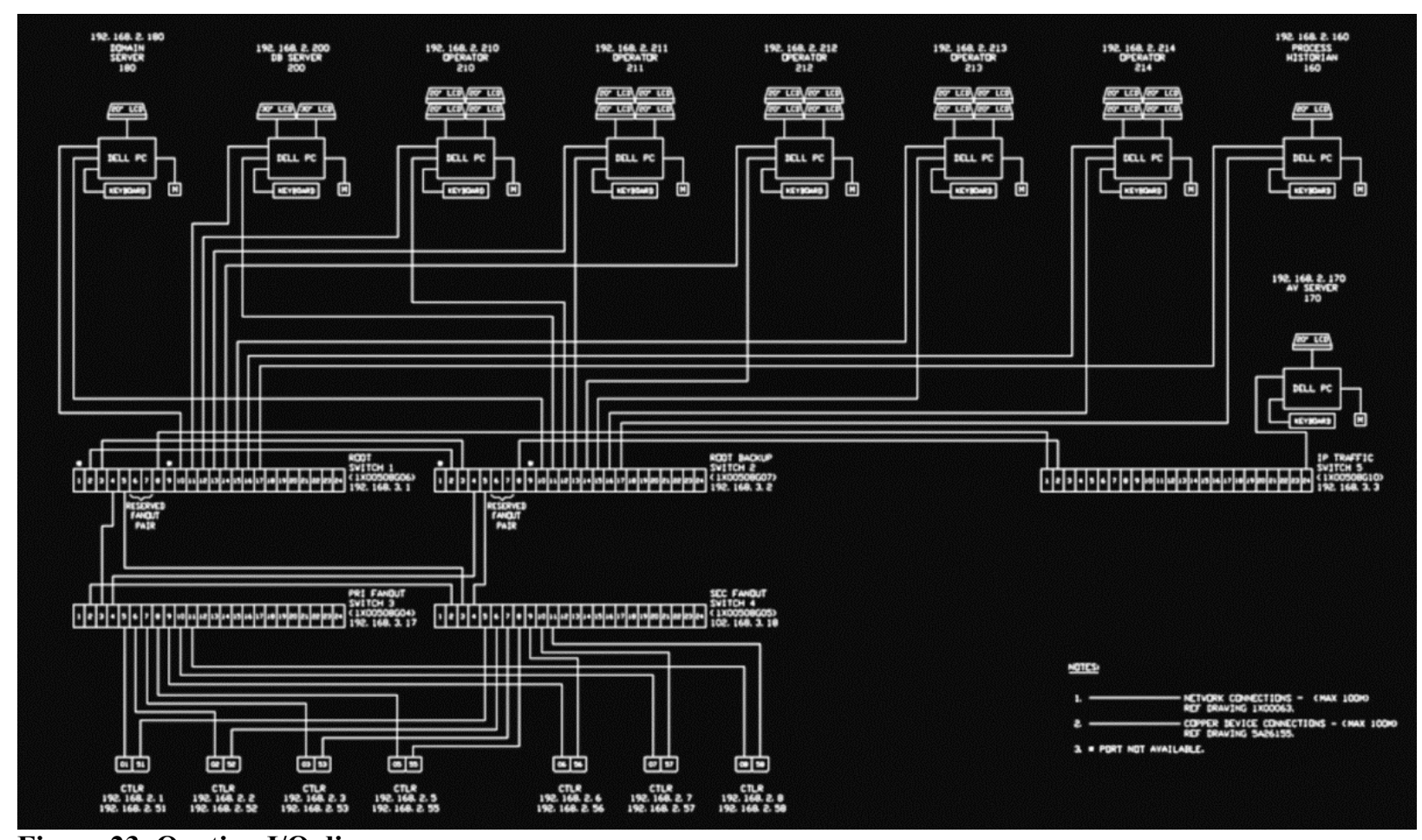

Figure 23. Ovation I/O diagram. 
The MMI of the facility DCS utilizes schematic-like drawings that generally reflect piping and instrumentation diagrams (Figs. 24 and 25). Control screens were created for each individual subsystem, spray bar nozzle control, annunciation (see Fig. 26), trending of spray bar pressures, and an overall icing system control display. The control screen expansion was made in the style of the existing facility screens to ensure a familial experience for the facility operators, with popup windows at the bottom of the screen for control actions.

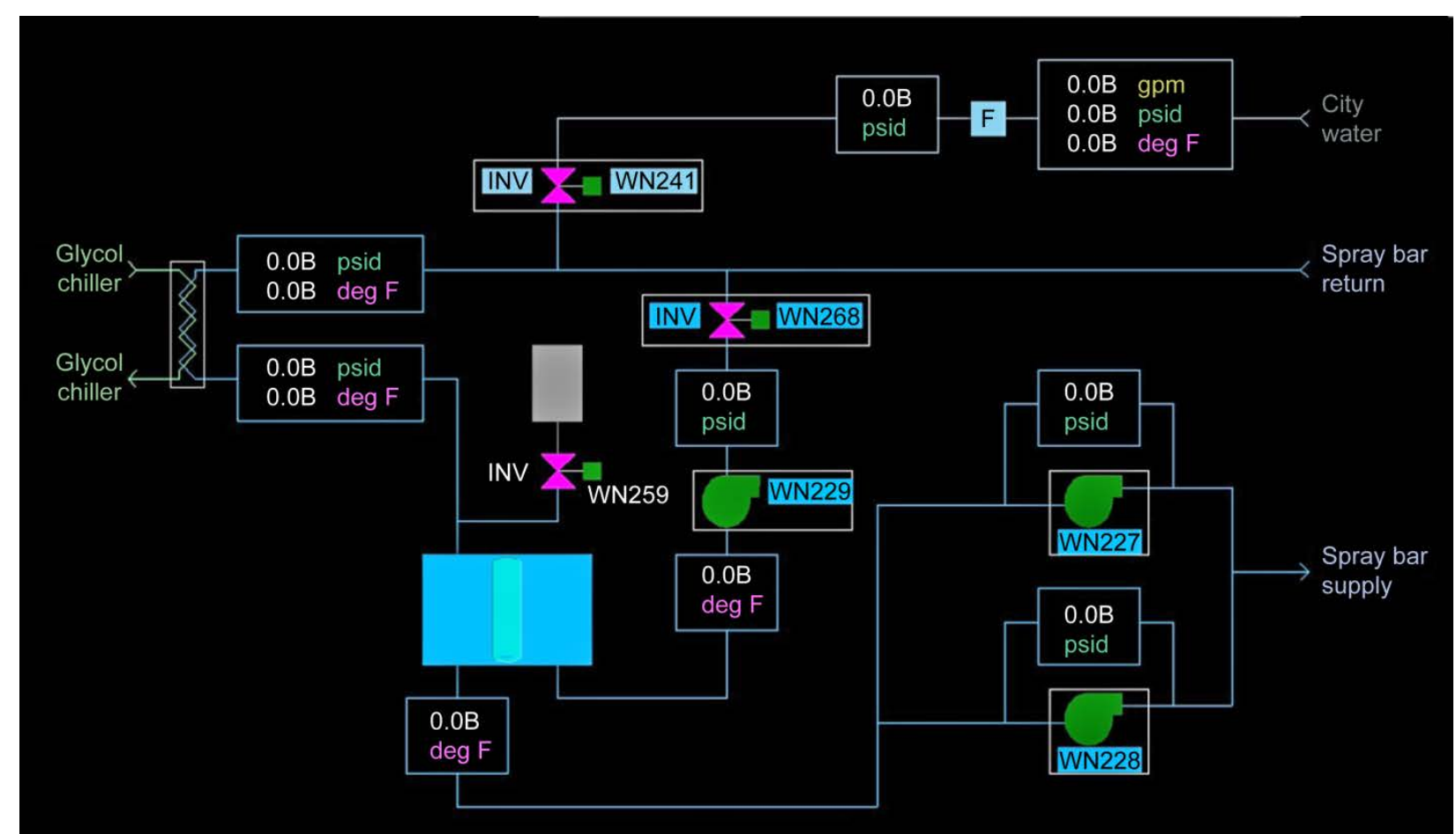

Figure 24. Ovation MMI screen, pump and valve control.

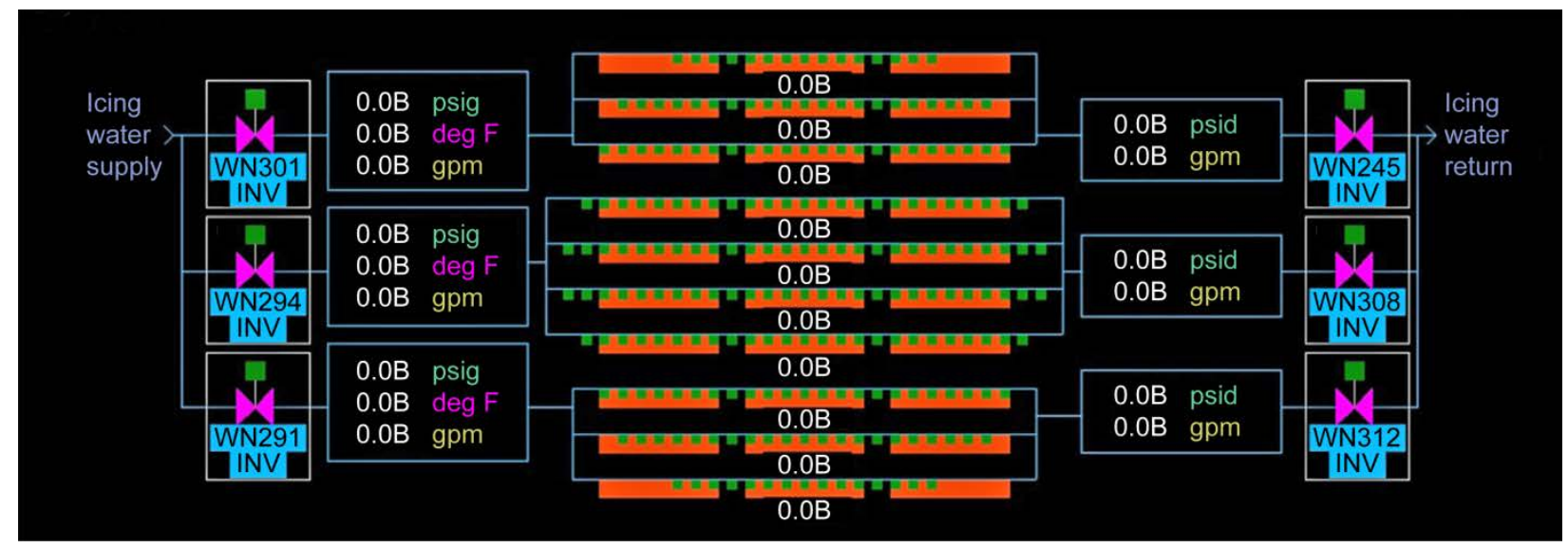

Figure 25. Ovation MMI screen, spray bar water regulator controls. 


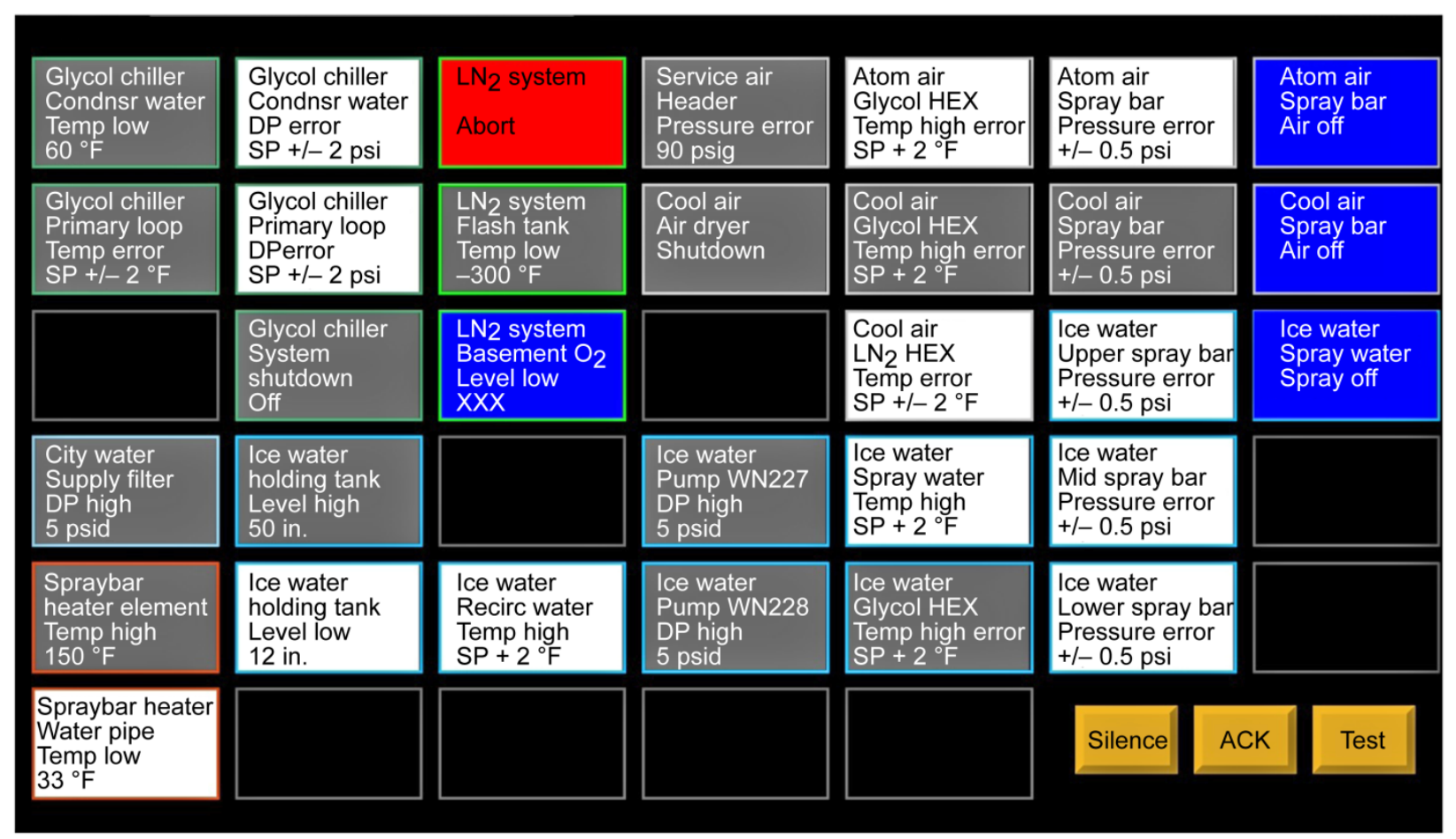

Figure 26. Ovation icing annunciators.

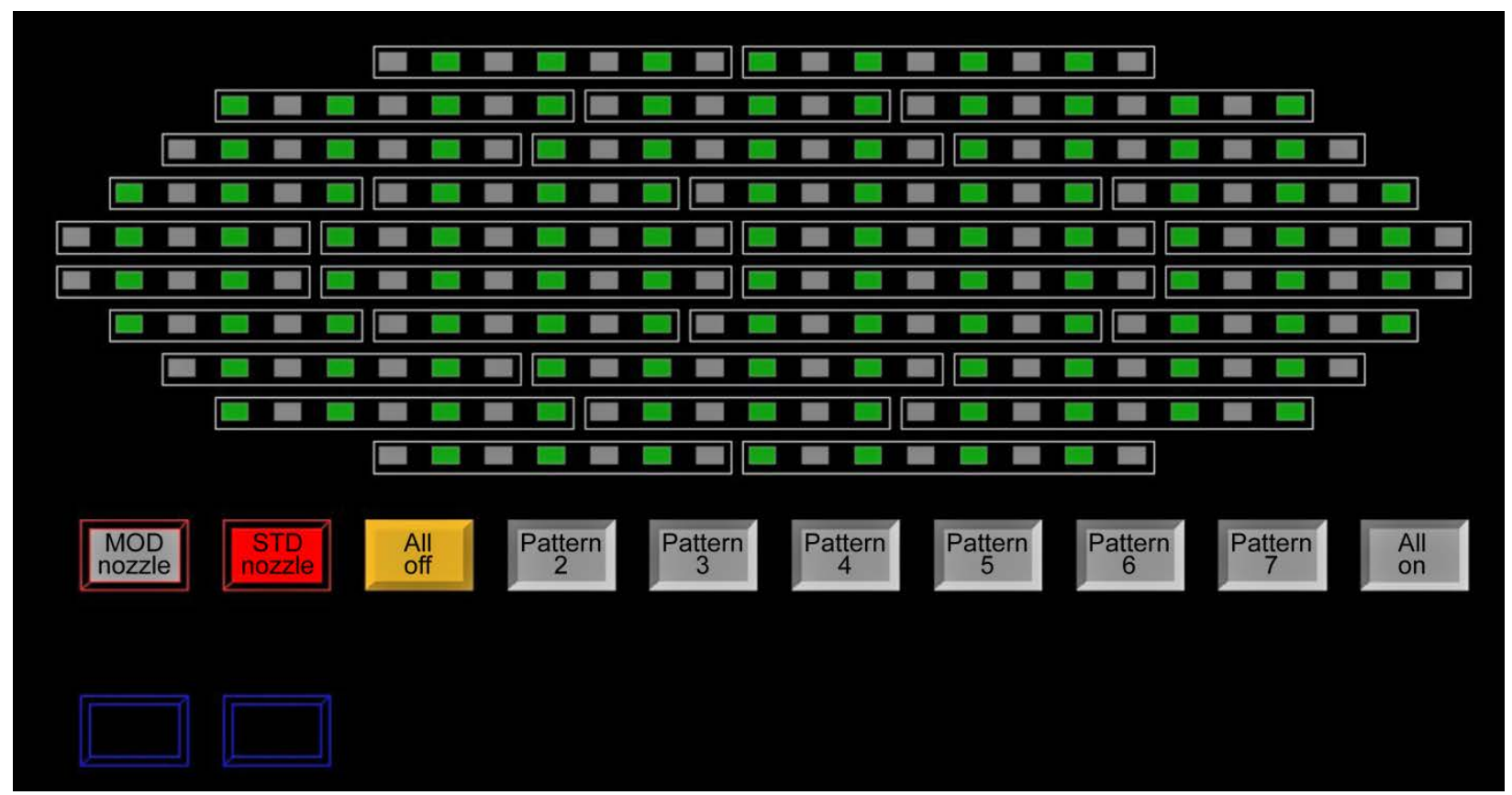

Figure 27. Ovation spray bar solenoid controls.

The spray bar control system (Fig. 27) permits the operator to select individual modules from eight programmable patterns. The pattern can be programmed to manually start and stop, or it can be programmed to spray for a predetermined length of time. The pattern can be modified on the fly as required by selecting or deselecting nozzles. The spray can also be aborted on demand.

In 2018 Emerson will drop the SureService support program for the WDPF Q-line I/O cards. The current plan is to initiate another Evergreen process in 2015 with a further upgrade to Ovation 3.5 and replace all remaining Q-line cards with current Ovation I/O cards. This change of $\mathrm{I} / \mathrm{O}$ cards can be accomplished without any modifications to 
field wiring, though the facility will be required to perform a complete end-to-end check of all signals and repeat the full integrated systems test before returning to testing.

\section{Ovation to ESCORT Data Transfer}

During operation of any aeronautical facility at NASA GRC, the practice is to not have the facility control system rely upon data acquired from the data system. The control system should be able to operate the facility without the data system being in scan. However, the reverse is not always true. Even though the Ovation system does have a Historian, which tracks and permits the recall of virtually every parameter in the system, it can be useful to integrate some of this data with the dataset acquired on the ESCORT steady-state data system. One must recognize that although the ESCORT data system is the data system of record and all of its measurements are traceable, the facility control system is not held to that standard. Ovation permits the use of OPC (object linking and embedding for process control) for the transmitting of points to other systems. In the case of the PSL, approximately 100 points are routinely sent to the ESCORT system for inclusion in the data set. The routinely included parameters are pressures, temperatures and valve positions from combustion air, auxiliary air, exhaust, fuel, cooling tower water, and hydraulic systems. During an icing test this OPC transfer list is doubled to include salient parameters from the icing system including pressures and temperatures from air, water, and spray bar and chiller systems as well as status from each of the spray nozzles.

\section{Auto Run Log}

The Auto Run Log system (Fig. 28) was originally designed for test conductors. Test conductors spent a considerable amount of their time writing down the critical test parameters for every test point to be used as an index for locating the points in the future. In addition the test conductor is expected to log observations on each point, observations which are not necessarily tied to a point, and actually keep overall awareness for the safety of the personnel, facility, and the article under test. Experience has shown that testing efficiency is largely dependent on the speed of the test conductor.

The Auto Run Log was designed to help ease the burden on test conductors by permitting the entry of observations for each data point taken without the need to laboriously log the numerous critical parameters. The use can configure the logger to fill in any of the data tags in the system. A new entry is created with each data system point taken, or on demand by the user. All of the desired parameters requested by the user would be filled in by the system for each observation or reading as an example, for a typical engine test this would include Time, Date, Reading Number, P0, P2, Altitude, Mach number, N1, N2, and EGT. The automatic logging of the numerous parameters greatly facilitates the active monitoring of the test, improved communication to the facility operators, and overall "heads up" testing.

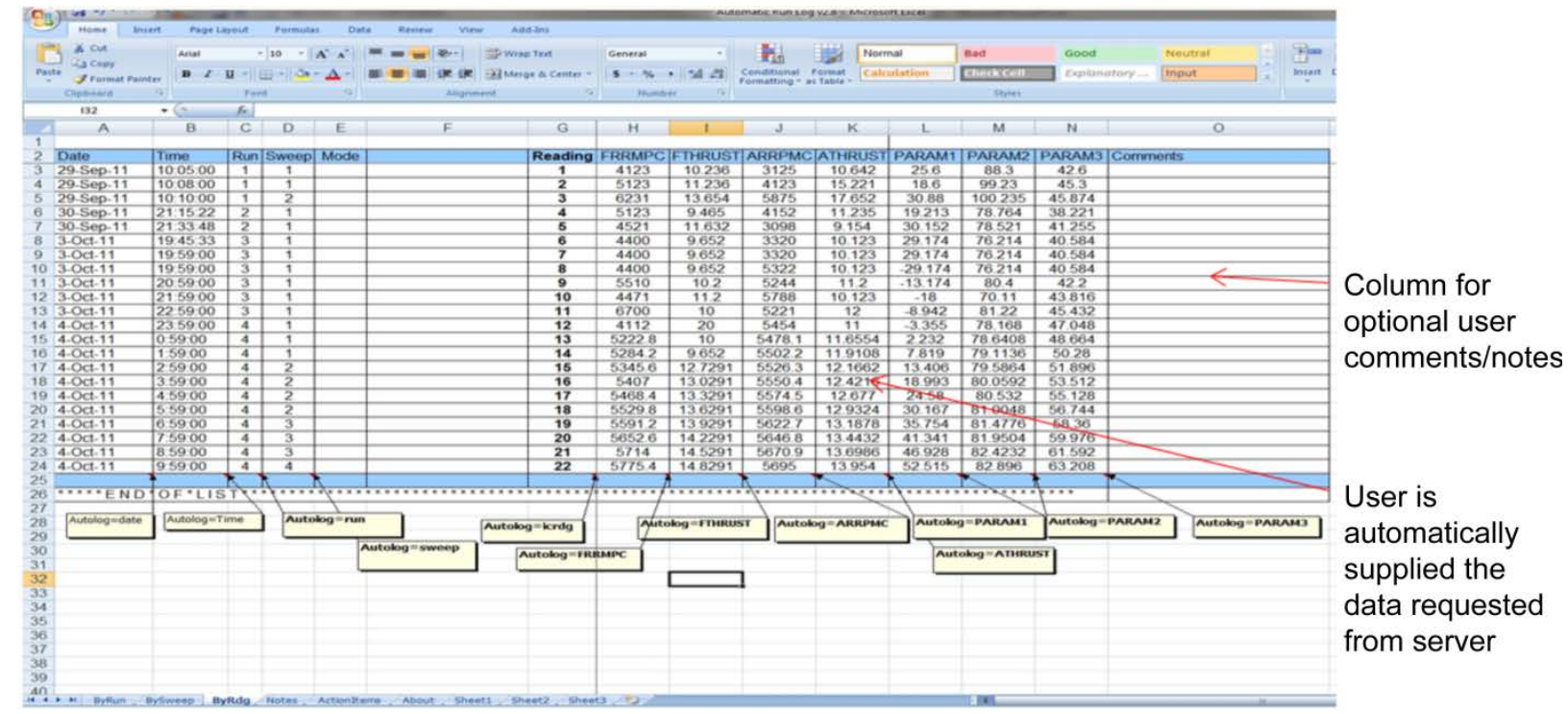

Figure 28. Auto Run Log spreadsheet. 


\section{Digital Temperature Scanner System}

PSL is transitioning from 1960s vintage ovens to a digital temperature scanner system. The Scanivalve DTS3250/64Tx thermocouple scanners (Fig. 29) provide for 64-channel thermocouple measurements. The first four units installed in PSL3 were used to augment the temperature measurement capability of the test cell, increasing the available customer channel count over 500 thermocouples. A similar upgrade is also underway in the companion PSL4.

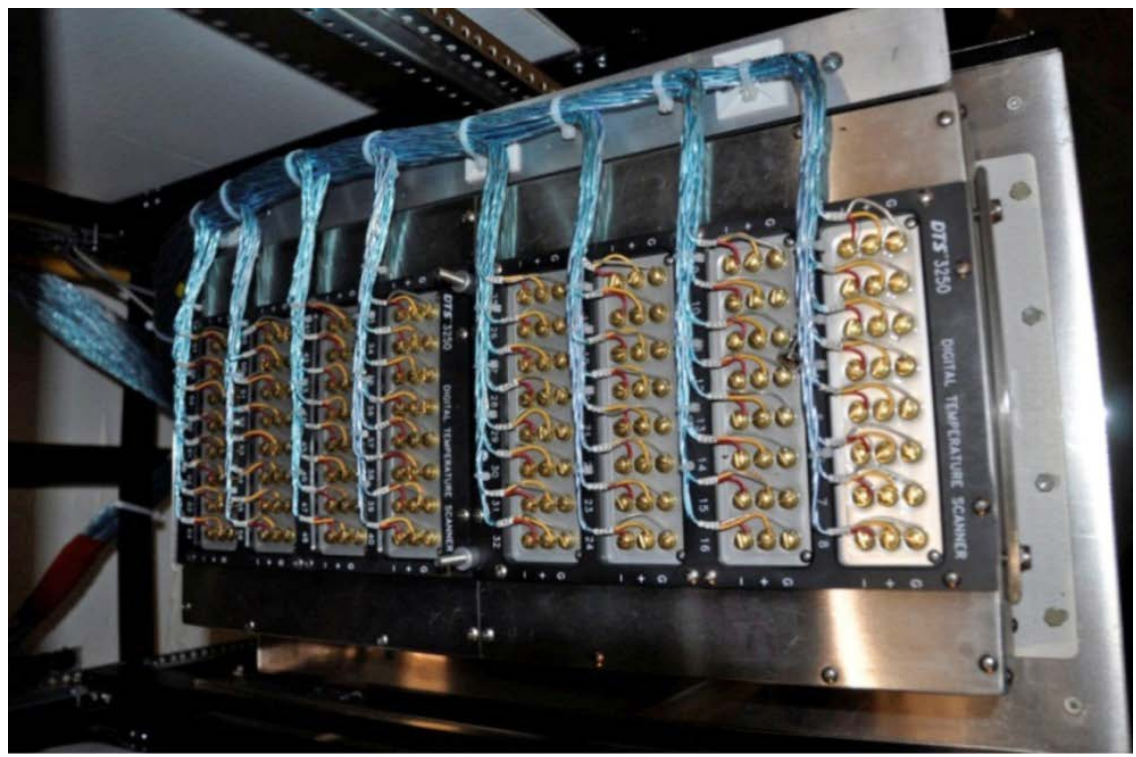

Figure 29. Scanivalve DTS module wiring.

Near-term plans include replacing the ten 48-channel ovens with eight 64-channel scanners in both PSL3 and PSL4.

This is just part of the first phase of a $\$ 4 \mathrm{M}$ plan to roll out large numbers of these systems, replacing all ovens and uniform temperature reference (UTR) block measurement devices with scanners over the next several years. The advantage of these units is the elimination of copper wiring and associated patch board contacts required with an oven or UTR as well as the reduction of A/D channels required by the next-generation data system.

\section{Conclusion}

The PSL has successfully added an engine altitude icing capability to PSL3 and has performed its inaugural test program. We have successfully calibrated our icing system and demonstrated we can simulate the icing conditions that caused the ALF502-R5 engine to roll back in flight test.

Subsequent to this first test program we have implemented several enhancements which should improve the capabilities of the system. We have added a low flow steam line, improved water vapor measurement system, improved spray bar heater and temperature measurements, and a de-ionized water system.

The PSL has a unique capability of being able to be used for simulated altitude icing studies and has been designed to offer a wide range of flight conditions and cloud properties. It would be a valuable resource to use for parametric studies of icing sensitivity without the risk or variability of a flight campaign.

\section{Acknowledgments}

This facility enhancement effort was funded by NASA AEST, and ATP programs. The authors wish to acknowledge and thank the superior effort given by the entire PSL team. Mechanical Engineers: Queito Thomas, Jack Kowalewski, and JP Kirkegaard;. Electrical Engineers: Steve Pesek, Bryan Rosine, and Vince Anton; Data Engineers: Pam Poljak, Morgan Pugh, and Kin Wong; Mechanical Technicians: Jeff Bobonik, John Wargo, Kent Smith, Adam Wasylyshyn, Jim Sexton, Jason Jacko, Chris Yager, and Jeff Luptak; Electrical/Electronic Technicians: Ken Trsek, Joe Switala, Dan Erbacher, Ryan Brown, Jeff Paulin, Mike Garapic, Eric Stevens, and John Brodkowski; the cloud specialists from the Icing Research Tunnel: Judy VanZante, Bob Ide, and Laura Steen; the Icing Research Branch: Michael Oliver, Gene Addy, and Paul Tsao; and the Optical Instrumentation Branch: Timothy Bencic, Amy Fagan, and Michelle Clem. 


\section{References}

${ }^{1}$ Soeder, Ronald H., Sheldon, David W., Ide, Robert F., Spera, David A., and Andracchio, Charles R., "NASA Glenn Icing Research Tunnel User Manual,"NASA/TM-2003-212004, 2003.

${ }^{2}$ Wright, W. B., "User's Manual for LEWICE Version 3.2," NASA/CR—2008-214255, 2008.

${ }^{3}$ Bidwell, C. S., and Potapczuk, M. G., "Users Manual for the NASA Lewis Three-Dimensional Ice Accretion Code (LEWICE3D)," NASA TM-105974, 1993.

${ }^{4}$ Mason, Jeanne, Strapp, J. Walter, and Chow, Philip, "The Ice Particle Threat to Engines in Flight," 44th AIAA Aerospace Sciences Meeting and Exhibit, Paper 2006-206, AIAA, Reston, VA, 2006.

${ }^{5}$ FAA Engine Harmonization Working Group, “Mixed-Phase/Glaciated Icing Technology Plan,” EHWG Technology Plan Document, Version 1.1, Dec. 20, 2005.

${ }^{6}$ VanZante, Judith F., and Rosine, Bryan M., "NASA Glenn Propulsion Systems Lab: 2012 Inaugural Ice Crystal Cloud Calibration Procedure and Results," 2014 AIAA Aviation, AIAA Meeting Papers on Disc [CD-ROM], AIAA, Reston, VA, 2014 (submitted for publication).

${ }^{7}$ Michael J., Oliver, "Validation Ice Crystal Icing Engine Test in the Propulsion Systems Laboratory at NASA Glenn Research Center," 2014 AIAA Aviation, AIAA Meeting Papers on Disc [CD-ROM], AIAA, Reston, VA, 2014 (submitted for publication).

${ }^{8}$ Bencic, Timothy J., et al., "Advanced Optical Diagnostics for Ice Crystal Cloud Measurements in the NASA Glenn Propulsion Systems Laboratory," Paper 2678, AIAA, Reston, VA, 2013. 